\title{
The Effects of Climate Change Impacts on Public Budgets and Implications of Fiscal Counterbalancing Instruments
}

\author{
Gabriel Bachner $^{1}$ (D) $\cdot$ Birgit Bednar-Friedl ${ }^{1,2}$ \\ Received: 27 April 2017 / Accepted: 7 June 2018 / Published online: 28 June 2018 \\ (C) The Author(s) 2018
}

\begin{abstract}
Climate change impacts have manifold effects on public budgets. In this paper, we therefore use a computable general equilibrium framework to consistently analyze how both the expenditure and revenue side of public budgets are affected via climate change impacts in ten different impact fields in Austria by mid-century. We then investigate different options how reductions in public service provision can be counterbalanced by fiscal instruments or by foreign lending and the associated economy-wide effects. We find that without counterbalancing, climate change impacts on the government budgets are doubled when considering not only the direct effect on the expenditure side but also macroeconomic feedback effects which reduce the overall tax base. With counterbalancing, we find significant differences in budgetary and macroeconomic consequences across fiscal instruments. While an increase of the capital tax as well as a cut in transfers reduce the welfare losses of climate change, higher labor taxes amplify welfare losses. This is because higher labor taxes dis-incentivize employing labor, thereby increasing unemployment and unemployment payments by the government. A higher output tax also increases welfare losses, but less strongly than an increased labor tax. Finally, increased foreign lending reduces welfare losses twice as much as the cut in transfers or the increased capital tax in the short term, but leads to a higher deficit and government debt.
\end{abstract}

JEL Classifications Q54 · Q58 · H23 · C68

Keywords Climate change $\cdot$ Impacts $\cdot$ Public finance $\cdot$ Tax policy $\cdot$ Policy analysis $\cdot$ Computable general equilibrium

\section{Introduction}

Fiscal sustainability or austerity is an important target for many countries across the world, which requires a balance between tax revenues and public expenditures on the national level. However, climate change impacts may lead to higher public expenditures for, e.g., disaster relief payments to households, or reconstruction of infrastructure [1], causing an imbalance in public budgets. But climate change impacts also have adverse effects on the private sector such as tourism or agriculture [2-4]. This reduction in sectoral output reduces the tax base and thus lowers tax revenues, aggravating the imbalance between higher expenditures and lower revenues.

Gabriel Bachner

gabriel.bachner@uni-graz.at

1 Wegener Center for Climate and Global Change, University of Graz, Brandhofgasse 5, 8010 Graz, Austria

2 Department of Economics, University of Graz, Universitätsstraße 15 / F4, Graz 8010, Austria
For a comprehensive assessment of climate change impacts on public budgets, it is therefore necessary to not only look into the direct effects of increased expenditures but also into the indirect effects of a reduced tax base [5, 6]. Eventually, the interplay of higher climate-induced expenditures on the one side, and reduced tax revenue on the other side, leads to less available budget for other public service provision such as health and education. In this paper, we thus analyze the combination of direct and indirect effects of climate change impacts on public budgets and explore different fiscal instruments to counterbalance the negative effects on public service provision and the respective macroeconomic consequences.

In the previous literature, the consequences of climate change for public budgets have been mostly addressed for mitigation. Both theoretical and empirical models were used to assess whether a double dividend emerges when a carbon tax or an emissions trading scheme is introduced and when revenues are used for reducing distortionary taxes [7-11]. A key finding in this literature is that the relative sizes of the tax interaction and the revenue recycling effect determine whether a double dividend arises or not (for a review, see $[12,13]$ ). 
Fischer and Fox [14] analyze how labor tax recycling can be used to reduce carbon leakage in case of a unilateral climate policy. Rausch [15] investigates how carbon pricing can be used to reduce government debt, i.e., to achieve fiscal consolidation. Franks et al. [16] compare a carbon tax to a capital tax as a means to finance public infrastructure and find that a carbon tax allows for capturing resource rents whereas capital taxes cannot be raised due to international tax competition.

For climate change impacts (and adaptation), the question of implications for public finance is a comparatively new one. In the context of budgetary consequences of climate change impacts, there are two key questions to be answered: (1) do climate change impacts infringe on the fiscal stability of a country, in the form of a budgetary failure, and (2) how do different climate change impacts affect the government budget?

The first question is strongly linked to the literature on sustainable debt levels. In the context of climate change, few papers and reports have addressed this question, mostly in the context of extreme events and natural disasters [17]. Hochrainer-Stigler et al. [18] assess the vulnerability of public finance to disaster risks by looking into the public sector's ability to rebuild public infrastructure and to undertake disaster relief payments to the affected population. The main finding from this strand of literature is that budgetary failure is a risk mostly for developing countries due to higher exposure and sensitivity [19].

Regarding the second question of how different climate change impacts affect the government budget, few studies investigate the effect of selected impacts on government budgets. Early estimates are provided by World Bank [20] who estimate additional investment requirements by the public sector and by Osberghaus and Reif [21] who provide back-of-theenvelope estimates for the direct costs of climate change for public budgets in the European Union. Lis and Nickel [6] use data from an extreme event database to estimate the impact of extreme events on the change in the budget balance for a panel of 138 countries. Leppänen et al. [22] estimate the effects of changes in climatic conditions for Russian regional government expenditures for the period 1999-2005 and find a comparatively small positive budgetary effect due to higher temperatures (milder winters). Delpiazzo et al. [23] investigate the budgetary implications of sea-level rise and adaptation in terms of changed public deficit. One shortcoming of the existing analyses (with the exception of [23]) is that they are limited to the direct effects on public expenditures, but they do not address the indirect impacts via changing government revenues due to sectoral and macroeconomic effects of climate change (for a qualitative review of both direct and indirect effects, see [24]).

To the best of our knowledge, this is the first paper that analyzes the direct and indirect effects of a wide range of climate change impacts to the government budget in such detail and in a consistent and comprehensive framework. We assess these impacts for the case of Austria by making use of a computable general equilibrium (CGE) model of the Austrian economy which takes account of climate change impacts in ten climate-sensitive sectors as well as public expenditures for disaster relief and reconstruction of public infrastructure [25, 26]. To ensure fiscal stability, we assume that the debt-to-GDP ratio needs to be constant, so that higher expenditures on climate-induced relief payments have to be balanced by reduced government spending on other purposes like education and health. To counterbalance such a reduction in public service provision, we analyze different fiscal instruments, as well as the option of foreign lending. While all of these instruments are set in such a way that public service provision is kept at the baseline level (without climate change), the instruments lead to significantly different effects in terms of the government revenues and expenditures, while also having different effects on welfare, GDP and employment.

The paper is structured as follows. Section 2 explains the methodology, starting with a non-technical description of the CGE model, followed by a qualitative description of the scenario framework, implemented climate change impacts, and finally the implemented fiscal instruments. Section 3 provides the results of the numerical quantitative analysis. Section 4 wraps up by discussing the results and giving conclusions.

\section{Methodology}

\subsection{Non-Technical Model Description}

To analyze the budgetary effects of climate change impacts, we use a single-country, comparative static computable general equilibrium (CGE) model of Austria (see Appendix for technical details and the algebraic formulation). The model covers 40 economic sectors using intermediate inputs as well as two production factors to create output according to nested constant elasticity of substitution (CES) production functions. Due to perfect competition and constant returns to scale, a zero profit condition holds for commodity markets and thus on these markets no monopoly rents arise.

There are two factors of production that generate income: labor and capital. Land and natural resources are not modeled separately but are part of capital and therefore capital rents also include land and resource rents. The representative private household is endowed with these two factors of production which generate her/his factor income. This factor income is spent for consumption (modeled as a nested CES function). Unemployment is modeled via a minimum wage. In addition to the representative private household, there is a government entity which provides public goods and services, financed by the following taxes: sales taxes on output, tax on capital gains, labor tax, value added tax, and export tax. All taxes are 
initially implemented as fixed rates and thus determine flexible government income, which in turn gives the total amount of available public budget. Regarding the labor market, the model includes unemployment, triggered by a minimum wage. International trade is depicted via the Armington assumption [27], i.e., domestic goods/services are not perfectly substitutable for goods/services coming from abroad. The foreign balance is fixed at the share of the benchmark year (2008).

\subsection{Scenario Framework}

In our model assessment, we distinguish between three types of scenarios: the Baseline (BL) scenario, the Climate Change scenario, and the Counterbalancing scenarios. All scenarios describe different developments from the model base year (2008) to 2050. The end point 2050 is chosen because detailed projections on socioeconomic development (population, land use etc.) and long-term government budget planning are available up to 2030, with rough estimates also available for the period up to 2050. No projections are available for later points in time. The Baseline scenario incorporates SSP2 only, but no climate change. The Climate Change and the Counterbalancing scenario incorporate SSP2 and climate change by 2050 according to SRES A1B.

All scenarios are situated in SSP2 [28], with intermediate challenges for mitigation and adaptation, from the model's base year to 2050. The implementation of SSP2 entails assumptions about population and settlement developments [29, 30], economic growth (1.65\% p.a. [31]), climate policy (via an exogenous $\mathrm{CO}_{2}$ price of $€ 41 / t$ [32]), as well as the energy [32] and agricultural [33] sector (see [34] for more details).

As we are interested in average climate change impacts, climate change signals for 2050 are calculated as average changes for the future 30-year climatic period 2036-2065 relative to the average of the base period 1981-2010. This is done for a "mid-range" climate scenario of a multi-model ensemble from the ENSEMBLES and the CMIP projects, downscaled to Austria (see figure 5.1 in [35]). The "midrange" climate scenario represents the SRES A1B emissions scenario, which corresponds to the RCP 4.5 scenario (global mean temperature change of $2{ }^{\circ} \mathrm{C}$ by end of the century). ${ }^{1}$ The localized climate scenario is generated from the Regional Circulation Model COSMO CLM [37] forced with the Global Circulation Model ECHAM5. For this mid-range climate scenario, we find the following climate signals on the Austrian level: average annual temperature increases by $2.02{ }^{\circ} \mathrm{C}$ relative to $1981-2010$, average precipitation

\footnotetext{
${ }^{1}$ As shown in the Austrian Assessment Report 2014 [36], the difference in climate signals between the different emission scenarios is very small until mid-century and only becomes more significant toward the end of the twentyfirst century. The focus on the A1B scenario is therefore no serious limitation of the current approach.
}

decreases by $9.2 \%$ in the summer half-year and increases by $6.5 \%$ in the winter half-year [35]. ${ }^{2}$

The Counterbalancing scenarios build on the Climate Change scenario but incorporate the additional constraint that the provision of public services should not decline. To achieve this target, different fiscal instruments are introduced in the model that guarantee stable (i.e., Baseline-level) public service provision. These fiscal instruments are described in more detail in Section 2.4 below.

To summarize our approach, we compare different versions of climate change impact scenarios (i.e., with and without counterbalancing) to the Baseline scenario, to isolate the macroeconomic effects of climate change impacts while holding climate mitigation policy, i.e., the $\mathrm{CO}_{2}$ price, constant. By comparing Baseline versus Climate Change and Baseline versus Counterbalancing, we can isolate the effects of the different counterbalancing instruments.

Regarding the development of the budget deficit, we assume that the government budget deficit grows at the GDP growth rate so that the deficit-to-GDP ratio remains constant over time (i.e., is the same in the base year and 2050), an assumption that is relaxed later on in one of the Counterbalancing scenarios. This is an empirically well-supported assumption for the structural deficit and is also in accordance with the Maastricht criteria. ${ }^{3}$ The (structural) debt level in the different scenarios can then be calculated by accumulating the deficit levels over the period 2010 2050 and adding them to the debt level (structural debt) in the base year. In the results section, we then report the changes in two common indicators for the financial stability of a country: the deficit-to-GDP ratio and the debt-to-GDP ratio.

\subsection{Climate Change Impacts and their Effects on Public Budgets}

Climate change impacts are identified and implemented across ten climate change "impact fields": Agriculture, Forestry, Water Supply and Sanitation, Buildings, Electricity, Transport, Manufacturing and Trade, Cities and Urban Green, Catastrophe Management, and Tourism. For each of these fields, several "impact chains"- describing stepwise the effects of changes of physical climate parameters to economic materialization - are quantified in separate analyses ${ }^{4}$ and then

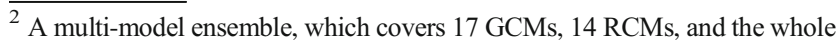
range of RCP emission scenarios, finds the following average impacts for Austria for the period up to 2050: average temperature increases range from 0.5 to $4{ }^{\circ} \mathrm{C}$, average annual precipitation in summer shows now clear trend, but precipitation in summer decreases in almost all simulations (up to $-20 \%$ ), and precipitation in winter increases by about the same amount [35].

${ }^{3}$ The Maastricht criteria, or convergence criteria, were agreed upon by EU member before the introduction of the Euro and include as one of the criteria the "Soundness and sustainability of public finances, through limits on government borrowing and national debt to avoid excessive deficit" [38]

${ }^{4}$ In order to achieve consistency, all of the (bio)physical impact models use the same assumptions regarding socio-economic developments and climate change. For details see [4].
} 
implemented into the macroeconomic CGE model via five different economic mechanisms: changes in production cost structures (e.g., a different production processes in Agriculture), changes in productivity (e.g., a lower productivity of the labor force in Manufacturing and Trade), changes in final demand (e.g., a shift from winter tourism to summer tourism), changes in investments (e.g., additional gas turbines to cover cooling peaks in Electricity), and/or changes in public expenditures (e.g., more relief payments undertaken by the government in Catastrophe Management). Table 1 summarizes the impacts which are implemented for each impact field as well as references to the (bio)physical impact models used for quantifying these impacts.

Figure 1 shows how the five different mechanisms trigger effects on public budgets. The first mechanism (1) affects the level and structure of public expenditure directly, e.g., if the government is confronted with higher payments to replace damaged infrastructure due to more extreme events. Mechanisms (2)-(5) affect the level of revenues via a changed tax base (6), e.g., via climate change-induced productivity losses which reduce sectoral output or labor demand. This change on the revenue side in turn indirectly co-determines the level of expenditures since expenditures have to equal revenues (7). The resulting change in the structure and level of expenditure also has indirect effects on the tax base (8); e.g., if the government is confronted with higher payments to replace infrastructure damages due to more extreme events, this triggers construction activity which changes the tax base again. The government is thus confronted with an interplay of climate change-triggered reductions of tax revenue and increases of expenditure, leading to a change in the provision of public services (9). In addition to these effects on the tax base and on the expenditure structure, macroeconomic effects also emerge within the general equilibrium framework.

\subsection{Counterbalancing Instruments}

Since a climate change-induced reduction of public services (e.g., health services, education or public infrastructure operation) is not desirable, we aim to keep expenditures on public service provision (i.e., government consumption in the CGE model) at the same level as in the baseline scenario without climate change. This "counterbalancing" can be done either by raising revenue, decreasing expenditure, or by foreign lending. We thus implement five different instruments for counterbalancing into the CGE model: (1) a uniform production output tax levied on all sectors ("Output Tax" scenario), (2) an increase in labor tax ("Labor Tax" scenario), (3) an increase in capital tax ("Capital Tax" scenario), (4) cuts in transfers to private households ("Transfer Cut" scenario), and (5) foreign lending ("Foreign Lending" scenario).
To illustrate how the different fiscal instruments work, we start with the analysis of the government balance which is given by:

$$
\begin{aligned}
\sum_{i} p_{i} G_{i, G O V} & +U B E N+\text { TRANS }=\omega \bar{L} \bar{t}^{L}+v \bar{K} \bar{t}^{K}+\sum_{i} p_{i} X_{i} \bar{t}_{i}^{X} \\
& +\sum_{i} p_{i} C \bar{t}_{i}^{C}+\sum_{i} p_{i} E X_{i} \bar{t}_{i}^{E X}+F O L E
\end{aligned}
$$

where the left-hand side represents government expenditures which consists of government consumption $\left(W G O V=\sum_{i} p_{i}^{G}\right.$ $\left.G_{i, G O V}\right)$, unemployment benefits (UBEN), and transfers to households (TRANS). Variable $p_{i}$ is the market price for commodity $i$, and $G_{i, G O V}$ is the government's consumption quantity of commodity $i$. The right-hand side represents the government revenues which is the sum of labor tax revenue $\omega \bar{L} \bar{t}^{L}$, capital tax revenue $v \bar{K} \bar{t}^{K}$, consumption tax revenue $\sum_{i} p_{i} C_{i} \bar{t}_{i}^{C}$, production tax revenue $\sum_{i} p_{i} X_{i} t_{i}^{X}$, export tax revenue $\sum_{i} p_{i} E X_{i} \bar{t}_{i}^{E X}$, and foreign lending FOLE (i.e., additional foreign lending which is initially set to zero). Variables $\omega$ and $v$ are the wage rate and the capital rent, $\bar{L}$ and $\bar{K}$ are total available labor and capital supply, $X_{i}$ is total production of $i, C_{i}$ is total consumption of $i, E X_{i}$ are exports of commodity $i$, and $\bar{t}$ is the respective exogenous input or output benchmark tax rate.

With climate change impacts, there are changes both on the left-hand side (i.e., a fraction of $W G O V$ is diverted from provision of other public services to, e.g., unemployment or climate-induced disaster relief payments) as well as on the right-hand side (i.e., a reduction in tax income due to a climate change induced reduction of the tax base). To ensure that nominal government expenditures ( $W G O V$ ) remains at the same level as in the baseline scenario, ${ }^{5}$ we implement different fiscal instruments.

In the Transfer Cut scenario, transfers to households denoted by variable TRANS are adjusted endogenously such that more financial resources can be allocated to $W G O V$.

In the Foreign Lending scenario, the variable FOLE is set endogenously to exactly the amount necessary to counterbalance the decline in revenue such that the baseline value of $W G O V$ is obtained. Note that in the Foreign Lending scenario we assume an additional influx of financial resources into the country, with the corresponding costs for repayment being considered as an annuity payment. ${ }^{6}$ While in the baseline scenario and in all other counterbalancing scenarios, we assume a constant deficit-to-GDP ratio, in the Foreign Lending

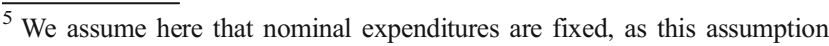
better describes budgetary reality than fixing real government services (keeping the quantity fixed): If expenditures, e.g., for wages in hospitals or schools increase, other one-time expenditures such as investment into new infrastructure has to be cut back, or delayed, accordingly. To provide a more complete picture, we include in the Appendix the key results when real government expenditures are fixed instead (Figures 8, 9, 10).

${ }^{6}$ This annuity is implemented in the model as a reduction of the effective annual capital availability.
} 


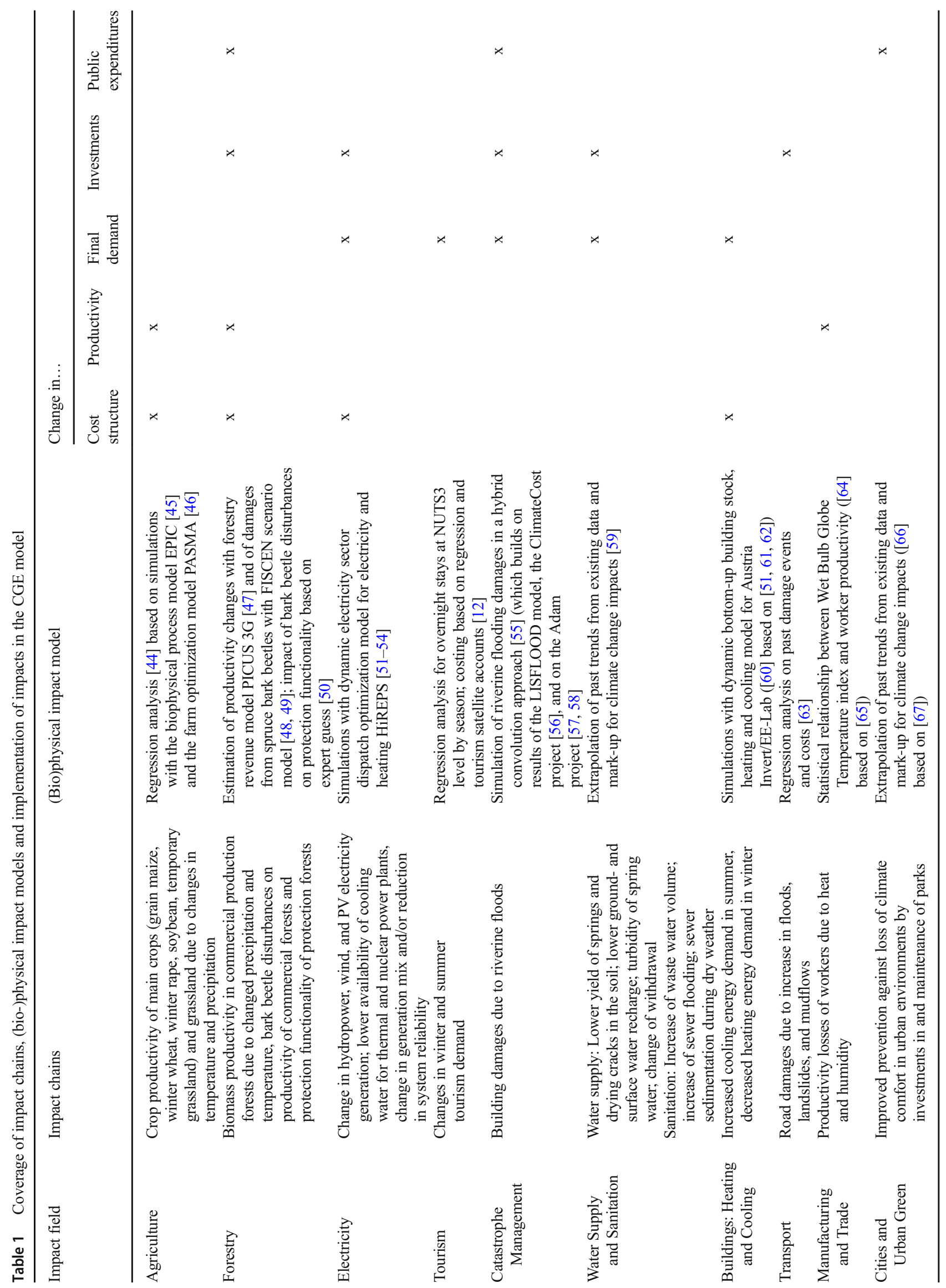


Fig. 1 Effects of climate change impacts on the provision of public services via different economic mechanisms. Black arrows show physical climate change impacts, gray arrows show direct effects, dashed arrows show indirect effects

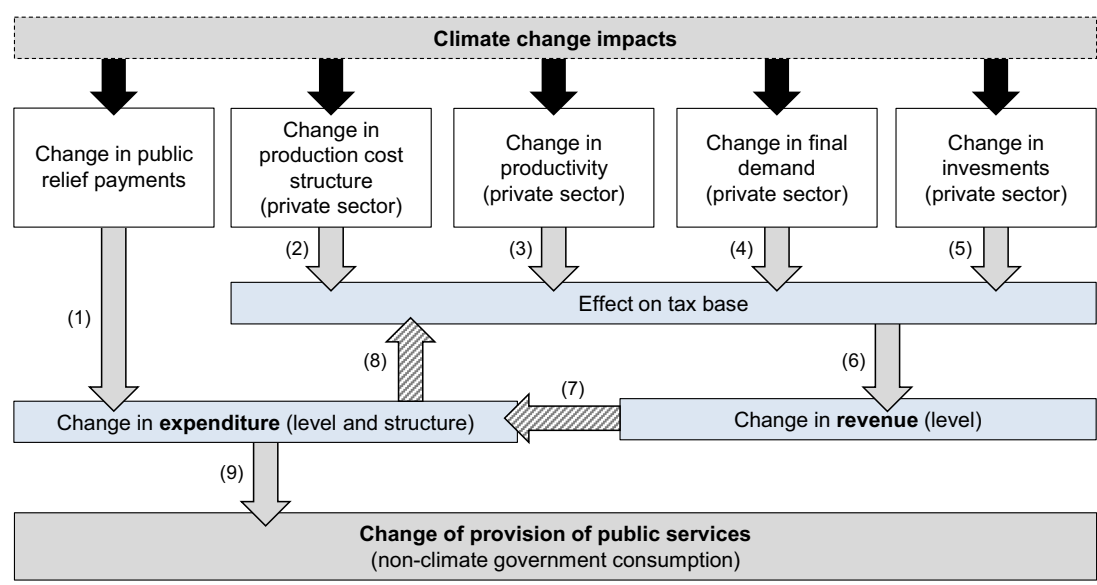

scenario, we relax this condition and allow for an additional deficit, which increases the deficit-to-GDP ratio.

The remaining fiscal instruments are implemented as tax scenarios (Output Tax, Labor Tax, and Capital Tax scenario). In the model, these input and output taxes alter sector-specific unit cost functions (see Appendix 2 for the exact nesting structures):

$c_{j}=\left[\sum_{i} \theta_{i}\left[p_{i}\left(1+\bar{t}_{i}^{I N}\right)\right]^{(1-\sigma)}\right]^{1 /(1-\sigma)} \frac{1}{1-\bar{t}_{j}^{O U T}}$

where $c_{j}$ are unit costs for production sector $j, \theta_{i}$ is the value share of production input $i$ (intermediate and factor inputs), $p_{i}$ is the price of input $i, \bar{t}_{i}^{I N}$ is the input tax rate on input $i$ and $\bar{t}_{j}^{O U T}$ is the tax rate on sector $j$ 's output, and $\sigma$ is the elasticity of substitution between inputs.

For the fiscal instrument Output Tax, the tax rate $\bar{t}_{i}^{\text {OUT }}$ is determined endogenously such that government's revenues increase sufficiently to obtain the same amount of $W G O V$ as in the baseline scenario. In the cases of fiscal instruments Labor Tax and Capital Tax, the respective tax rate $\bar{t}_{i}^{I N}$ changes endogenously in a similar manner. ${ }^{7}$ As a consequence of all three tax instruments, unit costs $c_{j}$ rise, leading to higher output prices and - in the Capital Tax and Labor Tax scenarioto higher factor prices as well. These effects in turn lead to substitution effects. In production, the shares of intermediate and factor inputs change across the whole economy, while in consumption, the composition of final demand changes, as well as the absolute level of consumption, since changing factor prices influence the household's disposable income.

For the numerical analysis, each instrument is treated as a single scenario, being then compared to a case without climate change (Baseline) and to a case with climate change but

\footnotetext{
${ }^{7}$ Note that all three tax instruments are implemented uniformly across all sectors, hence the same \%-point is added to the already existing (sectorspecific) taxes of the benchmark model.
}

without any counterbalancing ("No-Counterbalancing" scenario) to analyze the respective effects on government revenue, government expenditure, GDP, welfare, unemployment, and sectoral activity (turnover).

\section{Results}

\subsection{Effects of Climate Change on Public Budget without Counterbalancing}

Table 2 summarizes the effects of the different counterbalancing instruments. The first column shows the absolute values for the Baseline scenario without climate change (BL) in 2050, whereas the remaining columns show changes due to climate change with respect to BL (indicated by $\Delta \mathrm{CC}$ ) for the No-Counterbalancing case as well as for the five counterbalancing scenarios (i.e., instruments). We see that in the No-Counterbalancing scenario, total revenue and expenditure are $-0.3 \%$ lower than in the Baseline. On the revenue side, effects come mainly from lower labor tax revenue ($0.4 \%)$ and lower production tax revenue $(-0.8 \%)$.

In addition, climate change impacts increase expenditures on climate-induced disaster relief ${ }^{8}(+184 \%)$ and expenditures on unemployment benefits due to lower aggregate output $(+10 \%)$. These higher expenditures have to be compensated by a reduction in the provision of public services (non-climate government consumption). Since non-climate government consumption is relatively labor intensive, lower levels of consumption reduce labor demand and thus labor tax revenue declines. Taking both direct and indirect effects on government budgets together, and acknowledging that revenues and expenditures have to balance, yields a reduction in nonclimate government consumption by $-1.4 \%$. When

\footnotetext{
${ }^{8}$ Note that climate-induced relief payments are not simply growing with the same rate as GDP, but are calculated separately in the Baseline scenario and in the Climate Change scenario by using results from the LISFLOOD model [39] and estimates from $[40,41]$.
} 
Table 2 Changes of revenues, expenditures, and macro indicators for the climate change scenario with and without counterbalancing (given for 2050 in million $€_{2008}$ )

\begin{tabular}{|c|c|c|c|c|c|c|}
\hline BL & $\Delta \mathrm{CC}$ & $\Delta \mathrm{CC}$ & $\Delta \mathrm{CC}$ & $\Delta \mathrm{CC}$ & $\Delta \mathrm{CC}$ & $\Delta \mathrm{CC}$ \\
\hline Baseline & $\begin{array}{l}\text { No- } \\
\text { Counterbalancing } \\
\text { scenario }\end{array}$ & $\begin{array}{l}\text { Output Tax } \\
\text { scenario }\end{array}$ & $\begin{array}{l}\text { Labor Tax } \\
\text { scenario }\end{array}$ & $\begin{array}{l}\text { Capital Tax } \\
\text { scenario }\end{array}$ & $\begin{array}{l}\text { Transfer Cut } \\
\text { scenario }\end{array}$ & $\begin{array}{l}\text { Foreign Lending } \\
\text { scenario }\end{array}$ \\
\hline
\end{tabular}

\begin{tabular}{|c|c|c|c|c|c|c|c|c|c|c|c|c|c|}
\hline \multicolumn{14}{|c|}{ Government Revenues } \\
\hline Production tax & 25,670 & -202 & $-0.8 \%$ & +1739 & $+6.8 \%$ & -294 & $-1.1 \%$ & -158 & $-0.6 \%$ & -157 & $-0.6 \%$ & -151 & $-0.6 \%$ \\
\hline Labor tax & 119,797 & -468 & $-0.4 \%$ & -645 & $-0.5 \%$ & +4599 & $+3.8 \%$ & -255 & $-0.2 \%$ & -256 & $-0.2 \%$ & -258 & $-0.2 \%$ \\
\hline Capital tax & 26,863 & -11 & $-0.0 \%$ & -252 & $-0.9 \%$ & -781 & $-2.9 \%$ & +813 & $+3.0 \%$ & -8 & $-0.0 \%$ & -2 & $-0.0 \%$ \\
\hline Value-added tax & 39,516 & +54 & $+0.1 \%$ & -196 & $-0.5 \%$ & -697 & $-1.8 \%$ & -54 & $-0.1 \%$ & -54 & $-0.1 \%$ & +60 & $+0.2 \%$ \\
\hline Other taxes $* *$ & 14,140 & +43 & $+0.3 \%$ & -29 & $-0.2 \%$ & -27 & $-0.2 \%$ & -23 & $-0.2 \%$ & -23 & $-0.2 \%$ & -18 & $-0.1 \%$ \\
\hline $\begin{array}{l}\text { Climate change } \\
\text { induced foreign } \\
\text { debt }\end{array}$ & - & - & - & - & - & - & - & - & - & - & - & +770 & $+9.6 \% *$ \\
\hline $\begin{array}{l}\text { Total government } \\
\text { revenue }\end{array}$ & 225,986 & -584 & $-0.3 \%$ & +617 & $+0.3 \%$ & +2799 & $+1.2 \%$ & +324 & $+0.1 \%$ & -497 & $-0.2 \%$ & +383 & $+0.2 \%$ \\
\hline \multicolumn{14}{|c|}{ Government expenditures } \\
\hline \multicolumn{14}{|c|}{ Government consumption } \\
\hline $\begin{array}{l}\text { Non-climate } \\
\text { government } \\
\text { consumption }\end{array}$ & 123,054 & -1750 & $-1.4 \%$ & -547 & $-0.4 \%$ & -547 & $-0.4 \%$ & -547 & $-0.4 \%$ & -547 & $-0.4 \%$ & -547 & $-0.4 \%$ \\
\hline $\begin{array}{l}\text { Climate-induced } \\
\text { relief payments }\end{array}$ & 297 & +547 & $+184.0 \%$ & +547 & $+184.0 \%$ & +547 & $+184.0 \%$ & +547 & $+184.0 \%$ & +547 & $+184.0 \%$ & +547 & $+184.0 \%$ \\
\hline $\begin{array}{l}\text { Transfers to } \\
\text { households }\end{array}$ & 96,776 & +1 & $+0.0 \%$ & -34 & $-0.0 \%$ & +1 & $+0.0 \%$ & +1 & $+0.0 \%$ & -821 & $-0.8 \%$ & +3 & $+0.0 \%$ \\
\hline $\begin{array}{l}\text { Unemployment } \\
\text { benefits }\end{array}$ & 5859 & +618 & $+10.6 \%$ & +651 & $+11.1 \%$ & +2799 & $+47.8 \%$ & +323 & $+5.5 \%$ & +324 & $+5.5 \%$ & +380 & $+6.5 \%$ \\
\hline $\begin{array}{l}\text { Total government } \\
\text { expenditures }\end{array}$ & 225,986 & -584 & $-0.3 \%$ & +617 & $+0.3 \%$ & +2799 & $+1.2 \%$ & +324 & $+0.1 \%$ & -497 & $-0.2 \%$ & +383 & $+0.2 \%$ \\
\hline \multicolumn{14}{|l|}{ Macro indicators } \\
\hline GDP & 554,771 & & $-0.2 \%$ & & $-0.4 \%$ & & $-1.1 \%$ & & $-0.2 \%$ & & $-0.2 \%$ & & $-0.1 \%$ \\
\hline Welfare & 412,291 & & $-0.6 \%$ & & $-0.6 \%$ & & $-1.7 \%$ & & $-0.5 \%$ & & $-0.5 \%$ & & $-0.3 \%$ \\
\hline $\begin{array}{l}\text { Unemployment } \\
\text { rate (change in } \\
\% \text {-points) }\end{array}$ & $3.5 \%$ & & $+0.4 \%$ & & $+0.4 \%$ & & $+1.7 \%$ & & $+0.2 \%$ & & $+0.2 \%$ & & $+0.2 \%$ \\
\hline $\begin{array}{l}\text { Change in } \\
\text { debt-to-GDP } \\
\text { ratio }\end{array}$ & - & & - & & - & & - & & - & & - & & $+0.1 \%$ \\
\hline
\end{tabular}

*Gives change in annual deficit due to additional foreign lending

***Including revenue from $\mathrm{CO}_{2}$ tax

comparing the direct effect on government expenditure (i.e., additional annual public relief payments of $€ 574$ million) with the overall effects from the changed tax base (i.e., changes in tax revenue due to climate change impacts of $€ 584$ million p.a.), we see that revenue losses are of the same magnitude, meaning that the indirect effects should not be ignored, as they might severely affect available budgets.

Regarding the macroeconomic indicators, both GDP and welfare (measured by Hicksian equivalent variation) are lower compared to the BL (by $-0.2 \%$ and $-0.6 \%$ ) and unemployment is higher by $0.4 \%$-points.

Figure 2 illustrates which climate change impact fields contribute most to the total GDP and welfare effect for the No-
Counterbalancing scenario (relative to the Baseline). While positive effects are triggered in Agriculture and Heating \& Cooling (part of the "rest" category of impact fields), negative effects emerge from all other impact fields, particularly Forestry (due to reduced yields and higher pest infestations), Electricity (due to reduced potential from hydro power), Tourism (due to reduced winter tourism demand), and Catastrophe Management (higher expenditures on disaster compensation).

Figures 3 and 4 illustrate how each of the different impact fields contributes to the total effect on the different tax revenue and public expenditures categories (see Figs. 11 and 12 for absolute values). Impacts in the impact field Forestry translate 


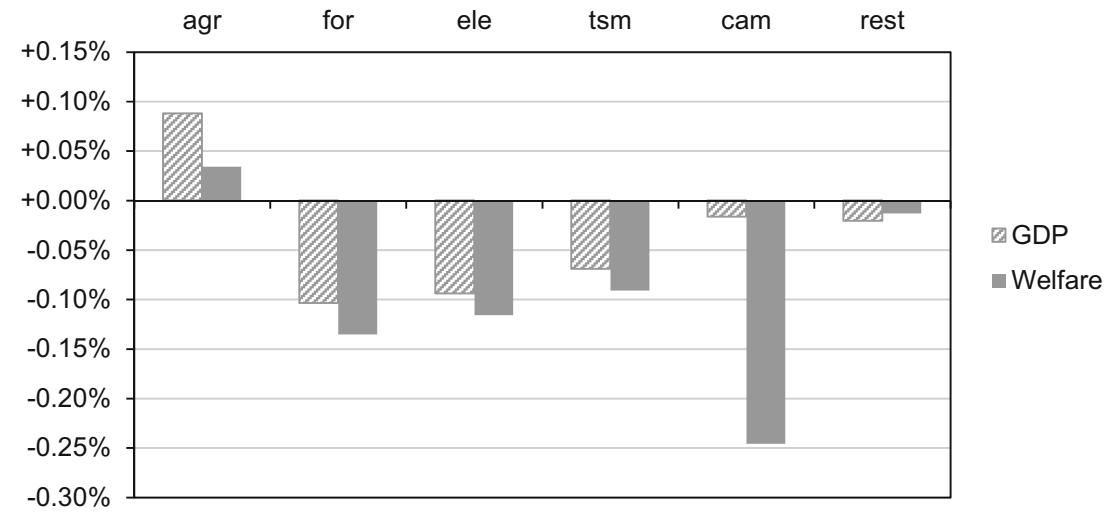

Fig. 2 Decomposed effects on GDP (shaded) and welfare (solid) across impact fields for the No-Counterbalancing scenario (relative to Baseline without climate change) for 2050 (average climate change impacts in period 2036-2065). Impact fields: Agriculture (agr), Forestry (for),

to the strongest decline in tax revenues (especially production and labor taxes), but impacts in the Electricity, Tourism and Catastrophe Management fields also substantially reduce tax income. When looking at the expenditure side, we see a similar pattern. The negative effects are dominated by impacts in the impact fields Forestry, Electricity, and Tourism.

\subsection{Effects of Counterbalancing}

Coming to the effects of the different counterbalancing instruments, we see in Table 2 that the effect on non-climate government consumption is now less pronounced, but by construction not zero because we allow for increasing climateinduced relief payments ( $€ € 547$ million) which are displayed as an extra line. When summing up the changes in non-climate government consumption and climate-induced relief payments, they add up to zero, meaning that the counterbalancing instruments exactly meet their targets.

Since we are interested in the effect of the different counterbalancing instruments, we compare the effects of the respective counterbalancing scenarios to the No-Counterbalancing scenario. Figures 5 and 6 show the effects on the revenue and

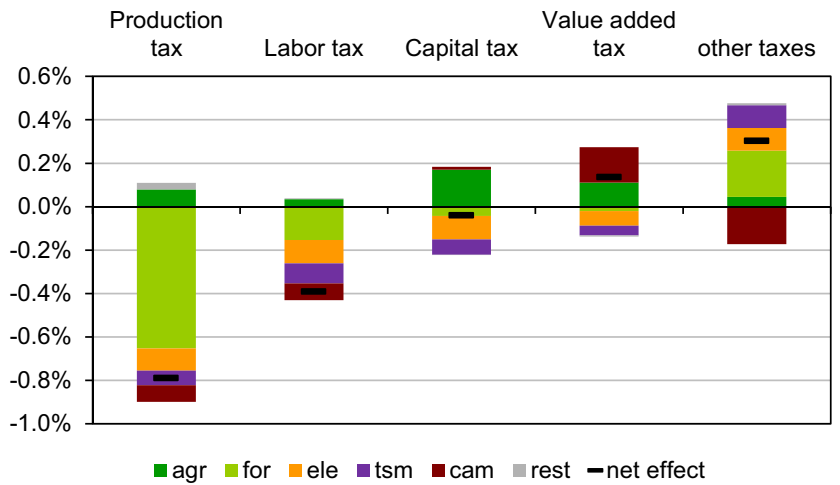

Fig. 3 Changes in government revenues in 2050 in the NoCounterbalancing scenario, by impact field and in total relative to Baseline scenario (= without climate change)
Electricity (ele), Tourism (tsm), Catastrophe Management (cam), and rest: Heating and Cooling, Water, Transport, Manufacturing and Trade, Cities and Urban Green

expenditure side, respectively, given as differences between NoCounterbalancing (relative to BL) and the counterbalancing scenarios (relative to BL) in \%-points. Figure 7 shows the changes for GDP, welfare, unemployment, and, for the Foreign Lending scenario, the change in the debt-to-GDP ratio.

In the Output Tax scenario, the endogenously determined additional output tax $\bar{t}_{j}^{O U T}$ to counterbalance government consumption is $0.2 \%$. On the revenue side, this leads to higher production tax revenue of $+8 \%$-points, whereas all other tax income items show moderately negative effects. On the expenditure side, we see a positive effect on government consumption (the desired counterbalancing becomes visible here). Since economic activity is taxed at a higher rate, production and employment are lower (GDP and welfare, $-0.1 \%$-points). Thus, the stimulating effect of more labor demand via the counterbalancing of government consumption is overcompensated by the negative scale effect of the tax. Hence, unemployment benefit payments are also slightly higher.

In the Labor Tax scenario, the required additional input tax $\bar{t}_{i}^{I N}$ on labor is $4.7 \%$. This relatively strong effect is driven by a feedback loop: higher labor taxes incentivize employing less labor, thereby increasing unemployment benefits, which in turn requires even higher taxes to finance the additional benefits and the counterbalancing of government consumption. As expected, we see an increase in labor tax revenue (4\%-points higher); however, since economic activity is negatively affected via strong labor market effects, the government faces a lower tax base and thus receives lower revenues from capital and value added taxes ( -3 and $-2 \%$-points, respectively). The strong labor market effect becomes clearly visible on the expenditure side, where unemployment benefits are higher by $+37 \%$-points ( $+€ 2.2$ billion), but also when looking at GDP, welfare and unemployment $(-0.8,-1.1$, and $+1.3 \%$-points, respectively).

In the Capital Tax scenario, the required increase in the capital tax rate $\bar{t}_{i}^{I N}$ is $0.5 \%$. On the revenue side, the additional tax leads to higher tax revenue from capital of $+3 \%$-points with 


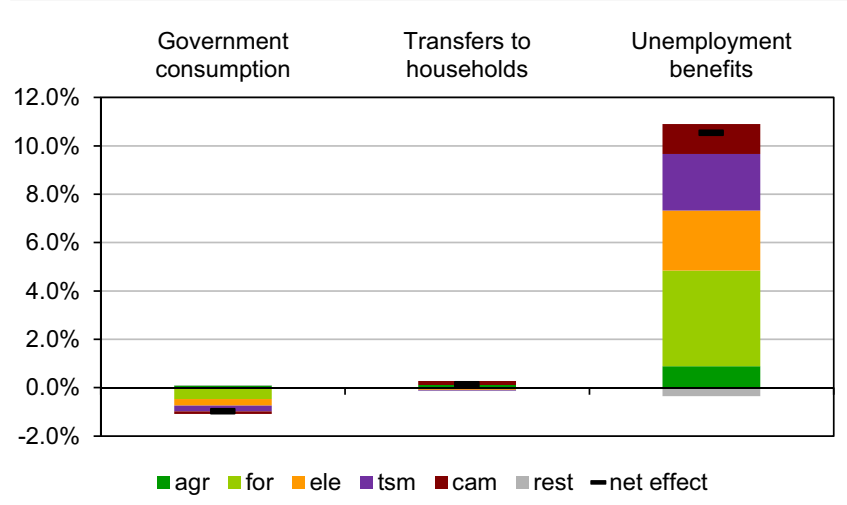

Fig. 4 Changes in government expenditure in 2050 in the NoCounterbalancing scenario, by impact field and in total relative to Baseline scenario (= without climate change)

only small effects on other tax revenues. Note that the effect on production and labor tax revenue is slightly positive, since production sectors shift from capital input to more labor input, leading to more labor demand. In addition, the stimulating effect of higher non-climate government consumption via the labor market becomes effective, leading to reduced unemployment (-0.2\%-points) and lower unemployment benefit payments (-5\%-points). GDP and welfare are affected positively.

In the Transfer Cut scenario, transfers to households (TRANS) need to be cut by $-0.8 \%$. On the revenue side, only the small indirect effects of this instrument become visible. There is slightly higher tax revenue coming from production and labor taxes (due to the stimulating effect of higher government consumption), but lower revenue from the value added tax, since there is less consumption possible for households in this case. On the expenditure side, non-climate government consumption increases (i.e., the counterbalancing) and transfers are cut. Unemployment benefit payments are lower since unemployment is lower as well (-0.2\%-points). GDP and welfare are higher by $+0.1 \%$-points.
In the Foreign Lending scenario, additional necessary foreign lending (FOLE) for counterbalancing is $€ 735$ million. This means that the annual deficit increases by this amount, which in relative terms is an increase of $+9 \%$. When relating the higher deficit to GDP, the annual deficit-to-GDP and debt-to-GDP ratio would increase by $0.1 \%$-points (as stated in Table 2 ). Since this increase in the deficit generates a temporary additional income, a positive stimulating effect again emerges from higher non-climate government consumption. This leads to lower unemployment (-0.1\%-points). GDP-as well as welfare - are positively affected $(+0.1$ and $0.3 \%$-points, respectively). However, when putting the additional debts into perspective, the positive GDP effect $(0.1 \%)$ vanishes since the debt-to-GDP ratio increases by about the same magnitude.

The effects of the different counterbalancing instruments on sectoral activity (quantity effect) are given in Table 3 . (Note that the model features 40 sectors; however, for presentation of results, we aggregated them to 10. See Table 4 in Appendix 2 for details.) In the Capital Tax, the Transfer Cut, and the Foreign Lending scenarios, counterbalancing generates a positive effect on service sectors, public administration, health, and entertainment, culture, and sports, since these four sectors cover about $95 \%$ of non-climate government consumption (Table 5). In the Output Tax scenario, however, these positive effects are less pronounced, in some cases becoming negative, as a result of output being taxed, which curbs economic activity slightly. Looking more closely at the Labor Tax scenario results, we see that the services, health, and entertainment, culture, and sports sectors show negative effects and public administration only a slight positive effect. Thus, although government consumption is balanced out successfully in terms of allocated budget (i.e., monetary absolute value, or in nominal terms) as indicated in Table 3, the actual provision of public services (in quantities, or real terms) is below the baseline level. This is due to strong price increases
Fig. 5 Effects on different tax revenues, for the five counterbalancing scenarios in 2050. Effects are given in \%-point difference between NoCounterbalancing (relative to BL) and the counterbalancing scenarios (relative to BL)

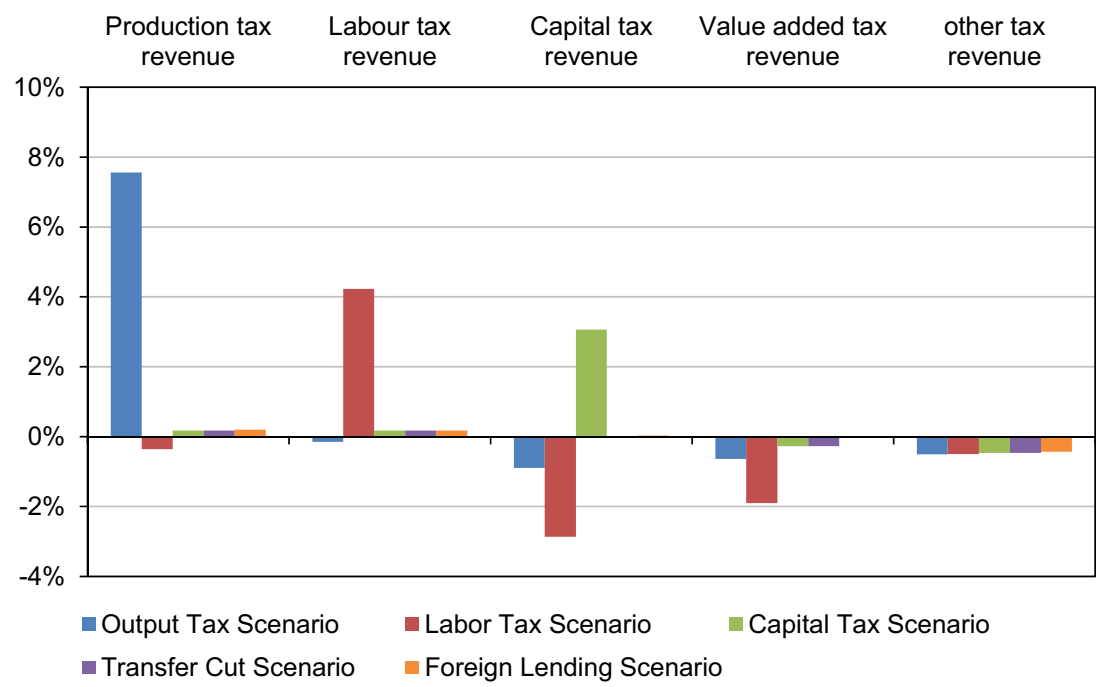


Fig. 6 Effects on the expenditure side, for the five counterbalancing scenarios in 2050. Effects are given in \%-point difference between No-Counterbalancing (relative to BL) and the counterbalancing scenarios (relative to BL)
Government consumption Transfers to households

Unemployment benefits

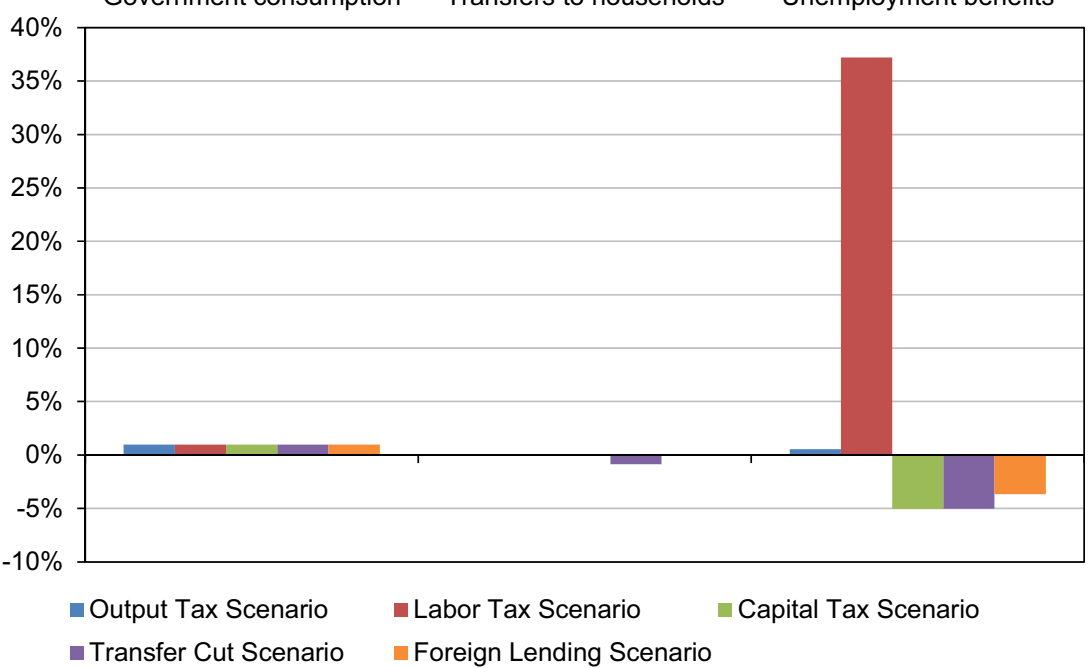

in the Labor Tax scenario such that the government spends the same amount for public service provision, but only can afford (and thus provide) less in terms of quantities. The same is true for the Output Tax scenario, but to a lesser extent. ${ }^{9}$

In order to check whether the qualitative results are robust with respect to the type and magnitude of different impacts, we additionally analyze in isolation the effects of all the fiscal counterbalancing instruments for the four most important impact fields (Forestry, Electricity, Tourism, Catastrophe Management), with the results given in Appendix 1 (Fig. 13). These four different climate impact fields work in different ways and have different magnitudes of effects on GDP and welfare (see Fig. 2). However, when applying the same set of counterbalancing instruments to each of these impact fields in separate runs, we see that the mechanisms behind the chosen instruments have very similar qualitative effects (or patterns) regarding GDP and welfare.

\section{Discussion and Conclusions}

In this paper, we address two research questions: How are public revenues and expenditure affected by climate change impacts? And, what are the macroeconomic effects of fiscal counterbalancing instruments? To give an answer to these questions, we deploy a computable general equilibrium (CGE) model for Austria, which features a rich set of climate change impacts in ten different climate sensitive sectors for a $+2{ }^{\circ} \mathrm{C}$ climate scenario until 2050 .

While different climate change impacts can have both positive and negative consequences for GDP and welfare, we find

\footnotetext{
${ }^{9}$ In Appendix 1 (Fig. 8 and 9), we also give the results when keeping real government consumption (quantities) constant. We see that effects are getting stronger, but do not change qualitatively.
}

that by 2050 the overall effect on GDP and welfare in Austria is clearly negative. Because of a reduced tax base, the impact on public revenues, and hence also on expenditures, is negative as well. Moreover, due to higher government expenditures on climate-induced relief payments, the scope for the provision of other public services is diminished even further.

When comparing the direct budgetary effects (i.e., additional climate change-induced relief payments) to the effects which emerge via the tax base (i.e., changes in tax revenue), we demonstrate the importance of economy-wide analyses, as we show that tax revenue declines by the same magnitude as relief payments increase, meaning that the gap between public income and necessary expenditures doubles, when also accounting for indirect effects.

In a mid-range climate change scenario, as presented here, the interplay of reduced tax revenue on the one hand and increased necessary payments on the other hand leads to a reduction of public service provision of $-1.4 \%$. It is therefore a legitimate question for whether fiscal counterbalancing instruments such as tax increases, cuts in transfers or foreign lending can mitigate this unfavorable side effect. In answering this question, we find that the type of instrument can strongly influence how the macroeconomy is affected, both in direction and magnitude of effects. While a rise in the capital tax, a cut in transfers or foreign lending reduce climate change-induced GDP and welfare losses (compared to the case without any counterbalancing instruments being implemented), a rise in the labor tax or output tax lead to increasing GDP and welfare losses. The reasons for this unfavorable effect in case of a higher labor tax is that unemployment and hence expenditures on unemployment payments increase, which reduces the scope for government demand and has overall strongly negative consequences for GDP and welfare. Furthermore, the Labor Tax scenario revealed that this fiscal instrument should be chosen with great care, as it may trigger strong increases in relative prices, lowering the purchasing power of the government's 
Fig. 7 Effects on selected macro indicators, for the five counterbalancing scenarios in 2050. Effects are given in \%-point difference between No-

Counterbalancing (relative to BL) and the counterbalancing scenarios (relative to BL)

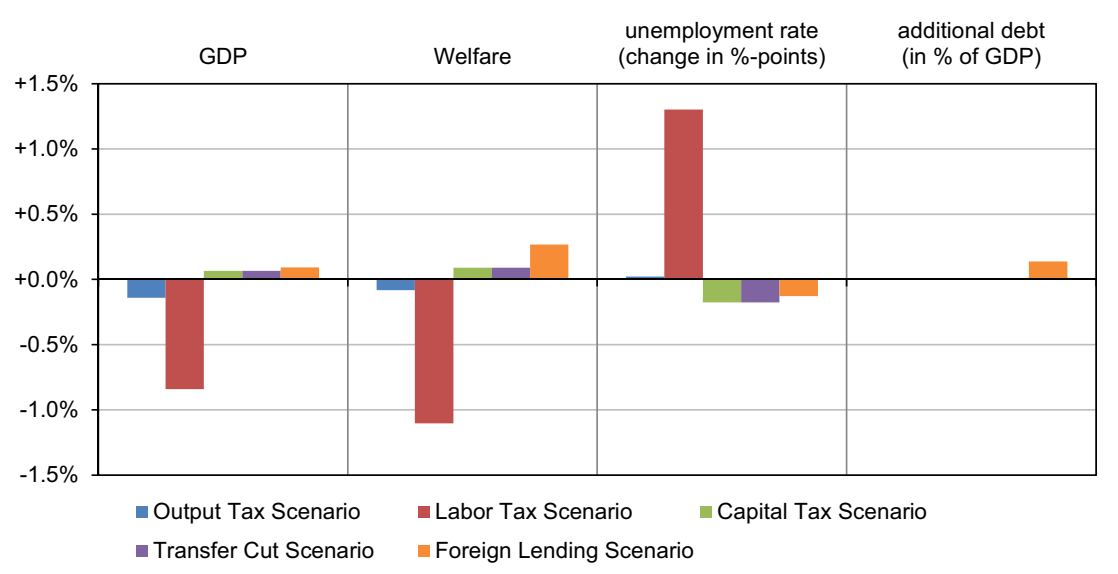

budget, leading in turn to lower actual public service provision than originally intended when implementing the instrument.

We find little difference between a cut in transfers and a rise in capital tax. Both instruments increase revenues or reduce expenditures compared to the case without counterbalancing. However, we did not look into distributional impacts across different income groups which such a cut in transfer might have for certain income groups. Similarly, due to our small open economy setting in which other countries are only reflected via their trade flows, we cannot address the question of capital flight and hence reduce public revenues. If this effect is strong, a rise in the tax rate might lead to a reduction in capital tax revenues instead of the increase which we find in our model. Moreover, it is important to note that capital use, as in most CGE models, is referring to returns on capital from the "real" (physical) capital stock, without considering the realworld complexity of financial markets.

Finally, increasing foreign lending has important long-term impacts when it comes to debt service. While we accounted for the increase in debt service due to the increase in foreign lending in terms of additional annuity repayments (corresponding to a $9 \%$ increase in the primary deficit which translates to an increase in the debt to GDP ratio by $0.1 \%$ ), we did not consider potential increases in interest rates due to a worsened debt rating of the government and we also ignored that higher interest payments reduce the future scope for public expenditures.

Clearly, when looking at GDP, welfare, and employment, the labor tax instrument is dominated by all other instruments and the output tax instrument is dominated by the other three instruments. Among these three instruments, the ranking depends on the preferences and policy targets underlying public decisionmaking. When current welfare, GDP, and unemployment are of key concern, foreign lending performs best. If in contrast an expansion in government debt is not allowed for, the capital tax increase and the cut in transfers are to be preferred. The decision among the latter two depends finally on how strongly concerns of distribution matter, and on the importance of capital flight.

As this paper is the first to investigate climate change impacts on government budgets in a comprehensive and consistent way, several aspects of the current analysis need to be
Table 3 Effects on sectoral activity, for the five counterbalancing scenarios relative to the NoCounterbalancing scenario

\begin{tabular}{llllll}
\hline & $\begin{array}{l}\text { Output Tax } \\
\text { scenario }\end{array}$ & $\begin{array}{l}\text { Labor Tax } \\
\text { scenario }\end{array}$ & $\begin{array}{l}\text { Capital Tax } \\
\text { scenario }\end{array}$ & $\begin{array}{l}\text { Transfer Cut } \\
\text { scenario }\end{array}$ & $\begin{array}{l}\text { Foreign Lending } \\
\text { scenario }\end{array}$ \\
\hline Primary sectors & $-0.1 \%$ & $+0.4 \%$ & $-0.1 \%$ & $-0.1 \%$ & $-0.2 \%$ \\
Manufacturing & $-0.4 \%$ & $-0.8 \%$ & $-0.0 \%$ & $-0.0 \%$ & $-0.2 \%$ \\
Construction & $-0.2 \%$ & $-0.4 \%$ & $-0.0 \%$ & $-0.0 \%$ & $-0.0 \%$ \\
Trade & $-0.3 \%$ & $-1.0 \%$ & $-0.1 \%$ & $-0.1 \%$ & $-0.1 \%$ \\
Transport & $-0.4 \%$ & $-1.1 \%$ & $-0.0 \%$ & $-0.0 \%$ & $-0.1 \%$ \\
Services* & $-0.2 \%$ & $-0.9 \%$ & $+0.1 \%$ & $+0.1 \%$ & $+0.1 \%$ \\
Pharmaceuticals & $-0.4 \%$ & $-0.9 \%$ & $-0.0 \%$ & $-0.0 \%$ & $-0.2 \%$ \\
Real estate & $-0.3 \%$ & $-0.6 \%$ & $-0.1 \%$ & $-0.1 \%$ & $+0.0 \%$ \\
Public adminstration* & $+1.0 \%$ & $+0.1 \%$ & $+1.1 \%$ & $+1.1 \%$ & $+1.0 \%$ \\
Health* & $+0.6 \%$ & $-0.5 \%$ & $+0.7 \%$ & $+0.7 \%$ & $+0.7 \%$ \\
Entertainment, & $-0.0 \%$ & $-0.7 \%$ & $+0.1 \%$ & $+0.1 \%$ & $+0.2 \%$ \\
\multicolumn{1}{c}{ culture, and sports } & & & & & \\
\hline
\end{tabular}

For sectoral aggregation, see Table 3 in the Appendix

*Main categories of government consumption 
addressed in future research. A risk management approach, integrating uncertainties on climatic and socioeconomic developments, would be an important next step so that real world policy makers can improve their budgetary planning. Second, additional research could integrate some of the unintended side effects of the counterbalancing instruments discussed above, such as capital flight or pronounced effects for some societal groups. Third, there might be additional, non-fiscal measures a government can take to counterbalance negative consequences of climate change.

Acknowledgements Open access funding provided by University of Graz. Funding for this research was granted by the Austrian Climate and Energy Fund under its 6th Call of the Austrian Climate Research Program (grant number B36862).

\section{Appendix 1 Additional Results and Sensitivity Analyses}

Table 4 Description of economic sectors, model codes, and aggregation for displaying results

\begin{tabular}{|c|c|c|c|}
\hline NACE code & Sector description & $\begin{array}{l}\text { Sector model } \\
\text { code }\end{array}$ & $\begin{array}{l}\text { Aggregation for } \\
\text { displaying results }\end{array}$ \\
\hline V01 & Crop and animal production, hunting and related service activities & AGRI & prim \\
\hline V02 & Forestry and logging & FORE & prim \\
\hline V86 & Human health activities & HEAL & heal \\
\hline V87_88 & Residential care activities; social work activities without accommodation & RECA & serv \\
\hline V36 & Water collection, treatment and supply & WATE & serv \\
\hline V37_39 & $\begin{array}{l}\text { Sewerage; waste collection, treatment and disposal activities; materials recovery; } \\
\text { remediation activities and other waste management services }\end{array}$ & WAST & serv \\
\hline V35 & Electricity, gas, steam, and air conditioning supply & ELEC & manu \\
\hline V19 & Manufacture of coke and refined petroleum products & COKE & manu \\
\hline V28_29 & $\begin{array}{l}\text { Manufacture of machinery and equipment n.e.c.; manufacture } \\
\text { of electrical equipment }\end{array}$ & $\mathrm{MACH}$ & manu \\
\hline V41_43 & Construction of buildings; civil engineering; specialized construction activities & CONT & cont \\
\hline V68 & Real estate activities & REAL & real \\
\hline V71 & Architectural and engineering activities; technical testing and analysis & $\mathrm{ARCH}$ & serv \\
\hline V45 & $\begin{array}{l}\text { Wholesale and retail trade and repair services of motor vehicles } \\
\text { and motorcycles }\end{array}$ & MOTO & manu \\
\hline V49 & Land transport and transport via pipelines & LTRA & trans \\
\hline V50 & Water transport & WTRA & trans \\
\hline V51 & Air transport & ATRA & trans \\
\hline V52_53 & $\begin{array}{l}\text { Warehousing and support activities for transportation; postal and } \\
\text { courier activities }\end{array}$ & STRA & trans \\
\hline V10, V12 & Manufacture of food products; manufacture of tobacco products & FOOD & manu \\
\hline V11 & Manufacture of beverages & BEVE & manu \\
\hline V16 & $\begin{array}{l}\text { Manufacture of wood and of products of wood and cork, except furniture; } \\
\text { manufacture of articles of straw and plaiting materials }\end{array}$ & WOOD & manu \\
\hline V17 & Manufacture of paper and paper products & PAPE & manu \\
\hline V20 & Manufacture of chemicals and chemical products & CHEM & manu \\
\hline V21 & Manufacture of basic pharmaceutical products and pharmaceutical preparations & PHAR & phar \\
\hline V22_23 & $\begin{array}{l}\text { Manufacture of rubber and plastic products; manufacture of other } \\
\text { non-metallic mineral products }\end{array}$ & PLAS & manu \\
\hline V24_25 & $\begin{array}{l}\text { Manufacture of basic metals; manufacture of fabricated metal products, except } \\
\text { machinery and equipment }\end{array}$ & META & manu \\
\hline $\begin{array}{l}\text { V13_15; V18, V26, } \\
\text { V27, V30_V33 }\end{array}$ & $\begin{array}{l}\text { Rest of manufacturing (manufacture of textiles; manufacture of wearing apparel; } \\
\text { manufacture of leather and related products; printing and reproduction of } \\
\text { recorded media; manufacture of computer, electronic and optical products; } \\
\text { manufacture of electrical equipment; manufacture of other transport } \\
\text { equipment; manufacture of furniture; other manufacturing; repair and } \\
\text { installation of machinery and equipment) }\end{array}$ & RMAN & manu \\
\hline V46_47 & Wholesale trade, except of motor vehicles and motorcycles; retail trade, except & TRAD & $\operatorname{trad}$ \\
\hline
\end{tabular}


Table 4 (continued)

\begin{tabular}{|c|c|c|c|}
\hline NACE code & Sector description & $\begin{array}{l}\text { Sector model } \\
\text { code }\end{array}$ & $\begin{array}{l}\text { Aggregation for } \\
\text { displaying results }\end{array}$ \\
\hline V64 & Financial service activities, except insurance and pension funding & FINA & serv \\
\hline V65 & Insurance, reinsurance and pension funding, except compulsory social security & INSU & serv \\
\hline V66 & Activities auxiliary to financial services and insurance activities & AFIN & serv \\
\hline V84 & Public administration and defense; compulsory social security & PUBL & publ \\
\hline V55_56 & Accommodation; food and beverage service activities & $\mathrm{ACCO}$ & serv \\
\hline V79 & Travel agency, tour operator and other reservation service and related activities & TRAV & serv \\
\hline V90 & Creative, arts and entertainment activities & ENTE & ecus \\
\hline V91 & Libraries, archives, museums and other cultural activities & CULT & ecus \\
\hline V93 & Sports activities and amusement and recreation activities & SPOR & ecus \\
\hline V03, V05_09 & $\begin{array}{l}\text { Fishing and aquaculture; mining of coal and lignite, extraction of crude } \\
\text { petroleum and natural gas, mining of metal ores, other mining and } \\
\text { quarrying, mining support service activities }\end{array}$ & REXT & prim \\
\hline V58 & Publishing activities & RECR & serv \\
\hline V59_60 & $\begin{array}{l}\text { Motion picture, video and television program production, sound recording } \\
\text { and music publishing activities; programming and broadcasting activities }\end{array}$ & & \\
\hline V92 & Gambling and betting activities & & \\
\hline V69_70 & $\begin{array}{l}\text { Legal and accounting activities; activities of head offices, management } \\
\text { consultancy activities }\end{array}$ & SCIE & serv \\
\hline V72 & Scientific research and development & & \\
\hline V73 & Advertising and market research & & \\
\hline V74_75 & Other professional, scientific and technical activities; veterinary activities & & \\
\hline V61 & Telecommunications & TELE & serv \\
\hline V62_63 & $\begin{array}{l}\text { Computer programming, consultancy, and related activities; information } \\
\text { service activities }\end{array}$ & & \\
\hline V95 & Repair of computers and personal and household goods & & \\
\hline V77 & $\begin{array}{l}\text { Rental and leasing activities } \\
\text { Employment activities }\end{array}$ & RSER & serv \\
\hline V80_82 & $\begin{array}{l}\text { Security and investigation activities; services to buildings and landscape } \\
\text { activities; office administrative, office support, and other business } \\
\text { support activities }\end{array}$ & & \\
\hline V85 & Education & & \\
\hline V94 & Activities of membership organizations & & \\
\hline V96 & Other personal service activities & & \\
\hline V97_98 & $\begin{array}{l}\text { Activities of households as employers of domestic personnel; undifferentiated } \\
\text { goods- and services-producing activities of private households for own use }\end{array}$ & & \\
\hline V99 & Activities of extraterritorial organizations and bodies & & \\
\hline
\end{tabular}

Table 5 Elasticities of substitution (based on Okagawa and Ban 2008)

\begin{tabular}{lllll}
\hline & $\mathrm{kl}$ & $\mathrm{kle}$ & int & top \\
\hline AGRI & 0.023 & 0.516 & 0 & 0.392 \\
FORE & 0.087 & 0.456 & 0.115 & 0.695 \\
REXT & 0.139 & 0.553 & 0.309 & 0.729 \\
FOOD & 0.328 & 0.395 & 0 & 0.329 \\
RMAN & 0.046 & 0.529 & 0.309 & 0.406 \\
PLAS & 0.358 & 0.411 & 0.191 & 0.306 \\
META & 0.22 & 0.644 & 0.253 & 1.173 \\
MACH & 0.295 & 0.292 & 0.459 & 0.13 \\
CONT & 0.065 & 0.529 & 0 & 1.264
\end{tabular}


Table 5 (continued)

\begin{tabular}{|c|c|c|c|c|}
\hline & $\mathrm{kl}$ & kle & int & top \\
\hline TRAD & 0.316 & 0.784 & 0.132 & 0.902 \\
\hline STRA & 0.31 & 0.281 & 0.331 & 0.352 \\
\hline RECR & 0.316 & 0.784 & 0.132 & 0.902 \\
\hline TELE & 0.37 & 0.518 & 0.711 & 0.654 \\
\hline SCIE & 0.316 & 0.784 & 0.132 & 0.902 \\
\hline RSER & 0.316 & 0.784 & 0.132 & 0.902 \\
\hline BEVE & 0.046 & 0.529 & 0.309 & 0.406 \\
\hline WOOD & 0.046 & 0.529 & 0.309 & 0.406 \\
\hline PAPE & 0.381 & 0.211 & 0 & 0.187 \\
\hline COKE & 0.334 & 0 & 0.082 & 0.848 \\
\hline CHEM & 0.334 & 0 & 0.082 & 0.848 \\
\hline PHAR & 0.046 & 0.529 & 0.309 & 0.406 \\
\hline ELEC & 0.46 & 0.256 & 0.391 & 0 \\
\hline WATE & 0.46 & 0.256 & 0.391 & 0 \\
\hline WAST & 0.46 & 0.256 & 0.391 & 0 \\
\hline МOTO & 0.316 & 0.784 & 0.132 & 0.902 \\
\hline LTRA & 0.31 & 0.281 & 0.331 & 0.352 \\
\hline WTRA & 0.31 & 0.281 & 0.331 & 0.352 \\
\hline ATRA & 0.31 & 0.281 & 0.331 & 0.352 \\
\hline $\mathrm{ACCO}$ & 0.316 & 0.784 & 0.132 & 0.902 \\
\hline FINA & 0.264 & 0.32 & 0 & 0.492 \\
\hline INSU & 0.264 & 0.32 & 0 & 0.492 \\
\hline AFIN & 0.264 & 0.32 & 0 & 0.492 \\
\hline REAL & 0.316 & 0.784 & 0.132 & 0.902 \\
\hline $\mathrm{ARCH}$ & 0.316 & 0.784 & 0.132 & 0.902 \\
\hline TRAV & 0.316 & 0.784 & 0.132 & 0.902 \\
\hline PUBL & 0.316 & 0.784 & 0.132 & 0.902 \\
\hline HEAL & 0.316 & 0.784 & 0.132 & 0.902 \\
\hline RECA & 0.316 & 0.784 & 0.132 & 0.902 \\
\hline ENTE & 0.316 & 0.784 & 0.132 & 0.902 \\
\hline CULT & 0.316 & 0.784 & 0.132 & 0.902 \\
\hline SPOR & 0.316 & 0.784 & 0.132 & 0.902 \\
\hline
\end{tabular}

Fig. 8 Effects on different tax revenues with constant quantities of government consumption (real expenditures), for the five counterbalancing scenarios in 2050. Effects are given in \%-point difference between No-

Counterbalancing (relative to BL) and the counterbalancing scenarios (relative to $\mathrm{BL}$ )

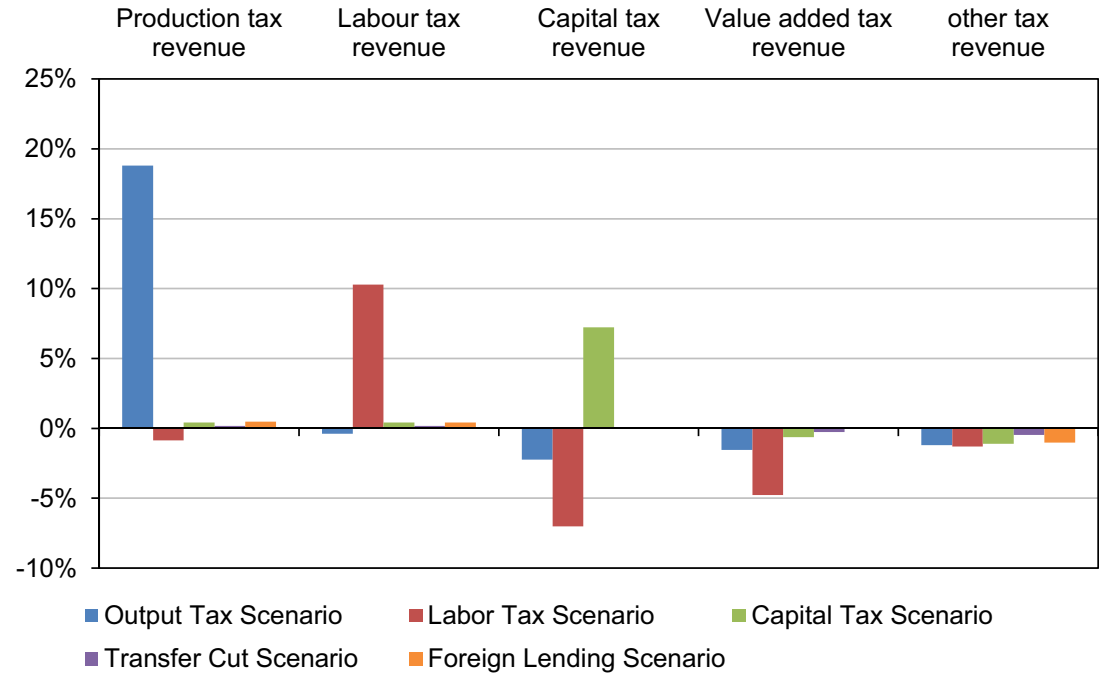


Fig. 9 Effects on the expenditure side with constant quantities of government consumption (real expenditures), for the five counterbalancing scenarios in 2050. Effects are given in \%-point difference between No-

Counterbalancing (relative to BL) and the counterbalancing scenarios (relative to BL)
Fig. 10 Effects on selected macro indicators, for the five counterbalancing scenarios in 2050 with constant quantities of government consumption (real expenditures). Effects are given in $\%$-point difference between NoCounterbalancing (relative to BL) and the counterbalancing scenarios (relative to BL)
Government consumption Transfers to households

Unemployment benefits
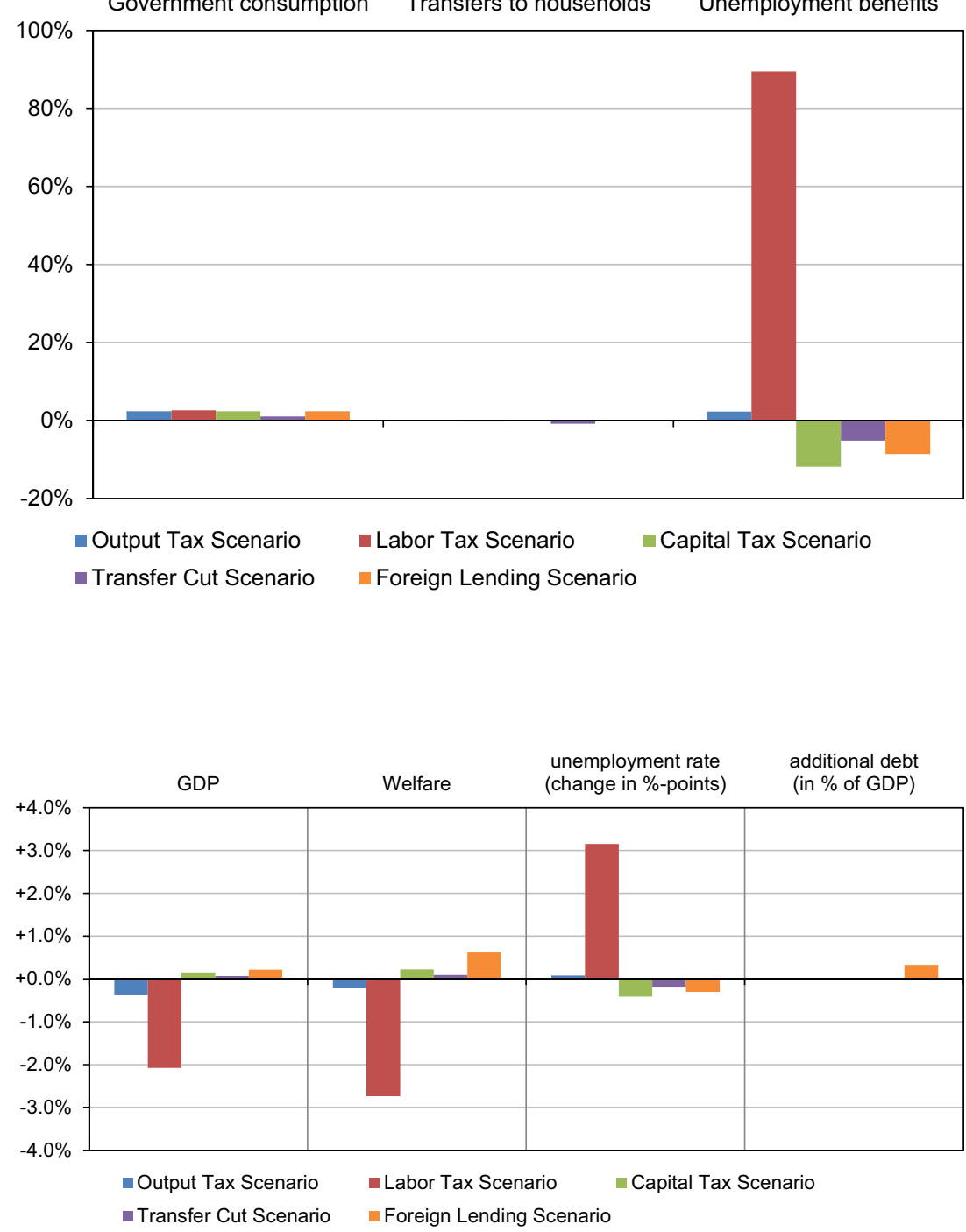

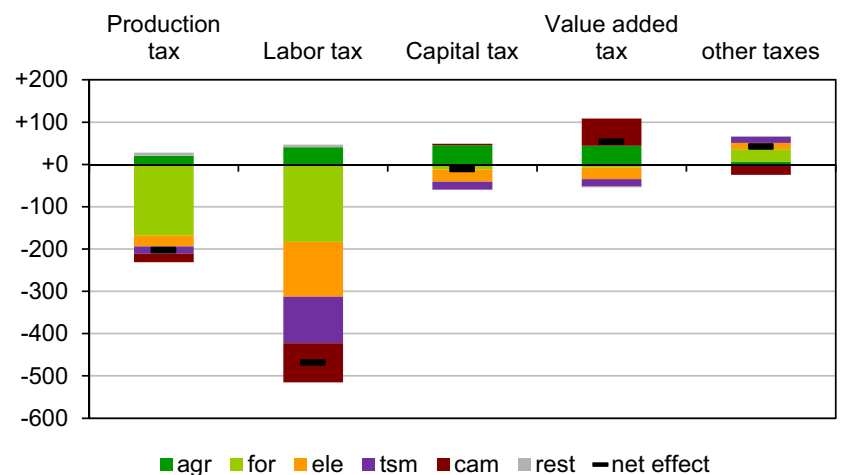

Fig. 11 Changes in government revenues in 2050 in the NoCounterbalancing scenario, by impact chain relative to Baseline scenario (= without climate change) (in million $€_{2008}$ )

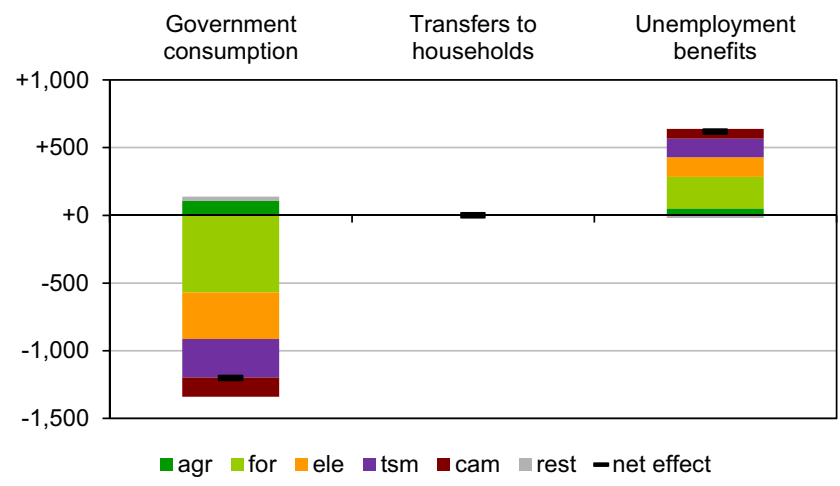

Fig. 12 Changes in government expenditure in 2050 in the NoCounterbalancing scenario, by impact chain relative to Baseline scenario (= without climate change) (in million $€_{2008}$ ) 
Fig. 13 Effects on selected macro indicators, for the five counterbalancing scenarios relative to the No-

Counterbalancing scenario, in isolation for the strongest impacts fields: Forestry, Electricity,

Tourism, Catastrophe

Management (a) Forestry only

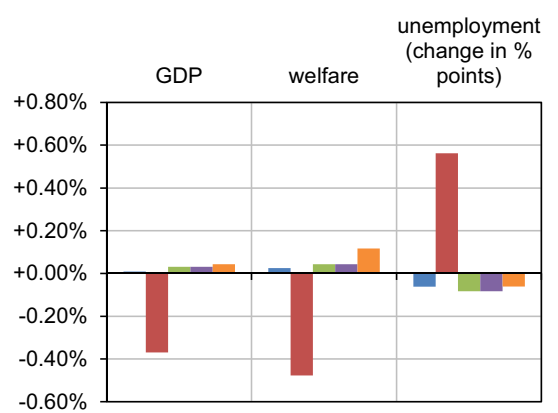

(c) Tourism only

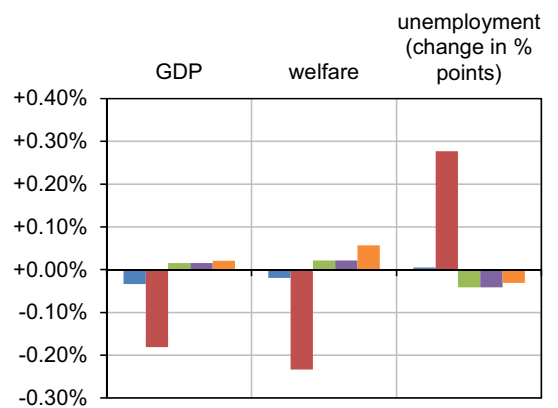

- Output Tax Scenario $\quad$ Labor Tax Scenario $\quad$ Capital Tax Scenario

- Transfer Cut Scenario = Foreign Lending Scenario (b) Electricity only

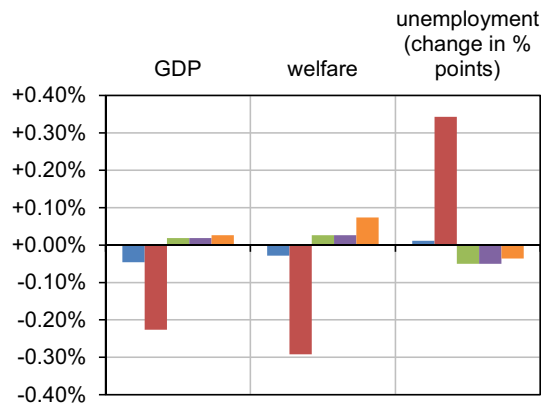

(d) Catastrophe Management only unemployment

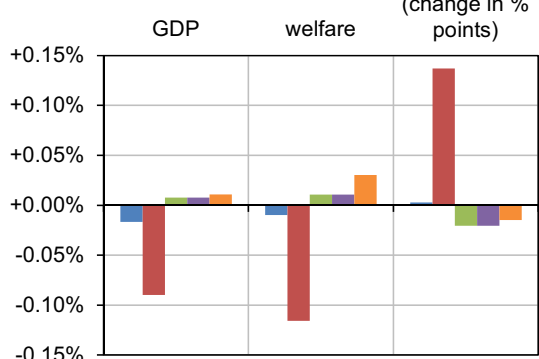

\section{Appendix 2 Model Description}

\section{General Model Description}

The production structure of domestic production $X$ is shown in Fig. 14. A nested constant elasticity of substitution (CES) production function is applied: On the top level of production of commodity $I$ a capital-labor-energy composite $((K L) E)$ can be substituted for an intermediate composite (INT) with the sector-specific elasticity of substitution top. On the second level of the nesting structure there are two branches: First, $(K L) E$ is produced by a capital-labor composite $(K L)$ and an energy composite $E$ which can be substituted with a sectorspecific elasticity kle. Second, INT is produced by intermediate inputs coming from an "Armington-aggregate" (including domestically produced commodities and imports), capturing all types of commodities, except COKE and ELEC $\left(G_{i}\right.$ to $\left.G_{k}\right)$. The intermediate inputs can be substituted against each other with the sector specific elasticity int. On the third nesting level the composite $K L$ is composed by $K$ and $L$, whereas the composite $E$ is composed by inputs from the sectors COKE and ELEC, respectively, with an elasticity of substitution of $k l$ and ene.

Concerning final demand of private households and the government, the welfare function is depicted in Fig. 15. On the top level a non-energy composite $(N E)$ can be traded off for the energy composite $E$ with an elasticity of substitution of $s$. Similar to the production structure of domestic production the $N E$ composite is produced using commodities $G_{i}$ to $G_{k}$ but
Fig. 14 Production structure of domestic production with three nesting levels

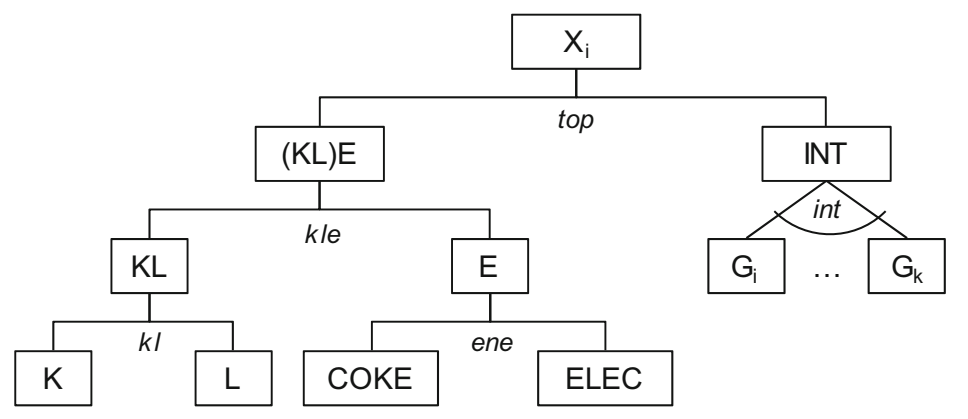

1 


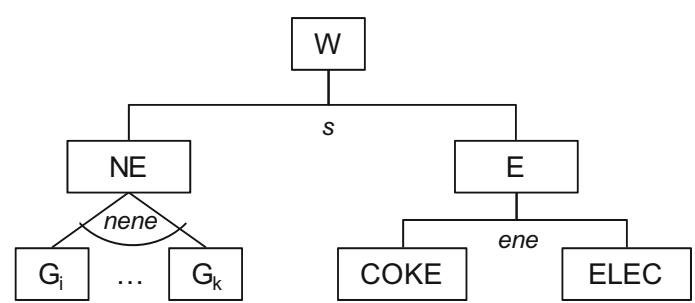

Fig. 15 Final demand structure of private households and government with two nesting levels

with a different elasticity of substitution (nene). The energy composite $E$ is produced in the same manner as in domestic production.

\section{Algebraic Model Formulation}

The CGE model is formulated as a system of non-linear inequalities. More precisely, the Arrow-Debreu economic equilibrium can be stated as a mixed complementarity problem (MCP) where three inequalities must be satisfied [42]: (1) zero profit condition for each commodity/sector, (2) market clearance condition, and (3) income balance condition. The first condition determines activity levels, the second price levels, and the third defines income levels. In the algebraic model formulation, the unit profit function $\pi_{i}^{Z}$ is used for notation. $Z$ is the regarded activity of sector (or commodity) $i$. The unit profit function is based on the constant elasticity of substitution (CES) production function in calibrated share form (see for example [43]). Initial benchmark data refers to the year of 2008.

\section{Zero Profit Conditions}

The zero profit condition requires that any production activity which produces positive quantities must earn zero profits. Thus, the value of inputs must be greater than or equal to the value of outputs. Therefore either a positive amount is produced and profits are zero or profits are negative and the output is zero.

Production of $X_{i}$ Unit profits $\pi$ of domestic production $X$ of sector $i\left(\pi_{i}^{X}\right)$ are determined by two parts: revenue per unit and unit costs. The former part is the domestic price $p$ of good $i\left(p_{i}^{D}\right)$ net of the sector specific domestic benchmark output tax $\bar{t}_{i}^{D}$. The latter part is determined by $\bar{C}_{i}^{X}$ (benchmark costs of item $i$ in domestic production $X$ ) which is divided by $\bar{X}_{i}$ (benchmark production of sector $i$ ). The resulting benchmark unit costs are then multiplied by sector-specific relative prices of inputs or input aggregates (equilibrium price $p_{i}$ divided by the benchmark price $\bar{p}_{i}$ ) which are weighted with sectorspecific value shares $\theta_{i}$ of inputs or input aggregates. Note that in the benchmark case, the whole term in curly brackets is equal to 1. Substitution elasticities between inputs or input aggregates are reflected by $\sigma$.

$\left.\pi_{i}^{X}=p_{i}^{D *\left(1-\bar{t}_{i}^{D}\right.}\right)-\frac{\bar{C}_{i}^{X}}{\bar{X}_{i}} *\left\{\theta_{i}^{K L E}\left(\frac{p_{i}^{K L E}}{\bar{p}_{i}}\right)^{1-\sigma_{i}^{\text {top }}}+\left(1-\theta_{i}^{K L E}\right)\left(\frac{p_{i}^{I N T}}{\bar{p}_{i}^{I N T}}\right)^{1-\sigma_{i}^{t o p}}\right\}^{\frac{1}{1-\sigma_{i}^{t o p}}}$

$\leq 0$ with $\perp X_{i}$

\section{Sector-Specific Capital-Labor-Energy Aggregate}

$\pi_{i}^{K L E}=p_{i}^{K L E}-\frac{\bar{C}_{i}^{K L E}}{\overline{K L E}_{i}} *\left\{\theta_{i}^{K L}\left(\frac{p_{i}^{K L}}{\bar{p}_{i}}\right)^{1-\sigma_{i}^{H l e}}+\left(1-\theta_{i}^{K L}\right)\left(\frac{p_{i}^{E}}{\bar{p}_{i}^{E}}\right)^{1-\sigma_{i}^{H l e}}\right\}^{\frac{1}{1-\sigma_{i}^{H C}}}$

$\leq 0$ with $\perp K L E_{i}$

\section{Sector-Specific Capital-Labor Aggregate}

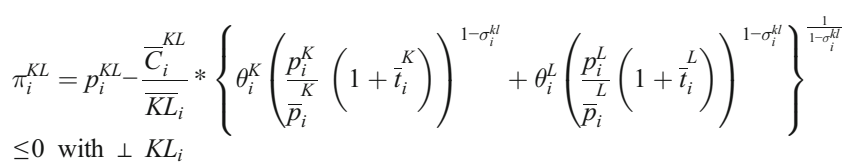

\section{Sector-Specific Energy Aggregate}

$\pi_{i}^{E}=p_{i}^{E}-\frac{\bar{C}_{i}^{E}}{\bar{E}_{i}} *\left\{\theta_{i}^{C O K E}\left(\frac{p_{i}^{G, C O K E}}{\bar{p}_{i}^{G, C O K E}}\right)^{1-\sigma_{i}^{\text {ene }}}+\theta_{i}^{E L E C}\left(\frac{p_{i}^{G, E L E C}}{\bar{p}_{i}, E L E C}\right)^{1-\sigma_{i}^{\text {ene }}}\right\}^{\frac{1}{1-\sigma_{i} \sigma_{e}}}$

\section{Sector-Specific Intermediate Aggregate}

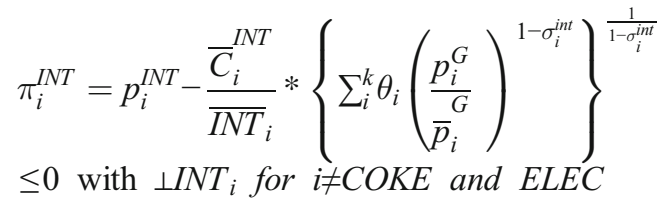




\section{Armington Aggregate}

$\pi_{i}^{G}=p_{i}^{G}-\frac{\bar{C}_{i}^{G}}{\bar{G}_{i}} *\left\{\theta_{i}^{D}\left(\frac{p_{i}^{D}}{\bar{p}_{i}}\right)^{1-\sigma_{i}^{a m i}}+\left(1-\theta_{i}^{D}\right)\left(\frac{p_{i}^{I M}}{\bar{p}_{i}}\right)^{1-\sigma_{i}^{a m i}}\right\}^{\frac{1}{1-\sigma_{i}^{a r m m}}}$

$\leq 0$ with $\perp G_{i}$

\section{Welfare of Private Household}

$\pi^{W}=p^{W}-\frac{\bar{C}^{W}}{\bar{W}} *\left\{\theta^{N E}\left(\frac{p^{N E}}{\bar{p}}\right)^{1-\sigma^{s}}+\left(1-\theta^{N E}\right)\left(\frac{p^{E}}{\bar{E}}\right)^{1-\sigma^{5}}\right\}^{\frac{1}{1-\sigma^{S}}}$
$\leq 0$ with $\perp W$

\section{Household Non-energy Consumption ${ }^{10}$}

$\pi^{N E}=p^{N E}-\frac{\bar{C}^{N E}}{\overline{N E}} *\left\{\sum_{i}^{k} \theta_{i}\left(\frac{p_{i}^{G}}{\bar{p}_{i}^{G}}\right)^{1-\sigma_{i}^{\text {nene }}}\right\}^{\frac{1}{1-\sigma_{i}^{n e n e}}}$

$\leq 0$ with $\perp N E$

\section{Welfare of Government}

$\pi^{W G O V}=p^{W G O V}-\frac{\bar{C}^{W G O V}}{\overline{W G O V}} *\left\{\theta^{N E}\left(\frac{p^{N E}}{\bar{p}^{N E}}\right)^{1-\sigma_{i}^{s}}+\left(1-\theta^{N E}\right)\left(\frac{p^{E}}{\bar{p}^{E}}\right)^{1-\sigma_{i}^{s}}\right\}^{\frac{1}{1-\sigma_{i}^{s}}}$

$\leq 0$ with $\perp W G O V$

Aggregate Imports and Exports Exports are used to create foreign exchange $(F X)$ which is used to purchase imports $(I M)$. In the benchmark SAM, there are positive net exports. The resulting excess $F X$ is assumed to be spent for investment (i.e., foreign investment).

$\pi^{E X}=p^{E X}-\frac{\bar{C}^{E X}}{\overline{E X}} *\left\{\sum_{i} \theta_{i}^{E X}\left[\frac{p_{i}^{E X}}{\bar{p}_{i}^{E X}}\left(1+\bar{t}_{i}^{E X}\right)\right]\right\} \leq 0$ with $\perp E X$

$\pi^{I M}=p^{I M}-\frac{\bar{C}^{I M}}{\overline{I M}} *\left\{\sum_{i} \theta_{i}^{I M}\left(\frac{p_{i}^{F X}}{\bar{p}_{i}^{F X}}\right)\right\} \leq 0$ with $\perp I M$

Domestic Supply Domestic supply $D$ is modeled as a constant elasticity of transformation (CET) function. Domestic production $X$ is either allocated to domestic supply $D$ (which is then used as input in the Armington aggregate $G$ ) or to exports $(E X)$.

$X_{i}=\left\{\theta_{i} D^{\rho}+\left(1-\theta_{i}\right) E X^{\rho}\right\}^{\frac{1}{\rho}}$

with $\rho=\frac{1-\sigma^{\text {armi }}}{\sigma^{\text {armi }}}$

\footnotetext{
${ }^{10}$ Household energy consumption is equivalent to sector specific energy aggregate.
}

Investment:

$\pi_{I N V}=p_{I N V}-\frac{\bar{C}_{I N V}}{\overline{I N V}_{I N V}} *\left\{\prod_{i}^{n}\left(\frac{p_{i}^{G}}{\bar{p}_{i}^{G}}\right)^{\theta_{i}}\right\}$
$\leq 0$ with $\perp I N V$

\section{Market clearance conditions}

The market clearance conditions require that all goods with a positive price must have a balance between demand and supply. Any goods in excess supply must have zero prices. Derivation of unit profit functions $\pi_{i}^{Z}$ with respect to prices gives the respective compensated demand quantities which must be smaller or equal to supply (Shephard's Lemma).

Labor Market Aggregate labor endowment $\bar{L}$ has to be larger than or equal to labor demand, which is the sum of all labor demanded by all sectors. Labor demand of sector $i$ is calculated by derivation of the unit profit function of domestic production of this sector $\pi_{i}^{X}$ with respect to the wage rate $\omega$ (price for labor) and multiplying it by the activity level of domestic production $X_{i}$. We allow for unemployment in equilibrium by applying a minimum wage $\omega$ which has to be equal or greater than the price of the welfare good $p^{W} . \bar{L}$ is rationed or expanded by an endogenous parameter such that this constraint is met. The change in this parameter then gives the change of unemployment.

$\bar{L} \geq \sum_{i} X_{i} \frac{\partial \pi_{i}^{X}}{\partial \omega}$ with $\perp \omega$

$\omega \geq p^{W}$

\section{Capital Market}

$\bar{K} \geq \sum_{i} X_{i} \frac{\partial \pi_{i}^{X}}{\partial v}$ with $\perp v$

Sector-Specific Energy Aggregate:

$\bar{E}_{i} \geq X_{i} \frac{\partial \pi_{i}^{X}}{\partial p_{i}^{E}}$ with $\perp p_{i}^{E}$

\section{Sector-Specific Capital-Labor Aggregate}

$\overline{K L}_{i} \geq X_{i} \frac{\partial \pi_{i}^{X}}{\partial p_{i}^{K L}}$ with $\perp p_{i}^{K L}$

Sector-Specific Capital-Labor-Energy Aggregate

$\overline{K L E}_{i} \geq X_{i} \frac{\partial \pi_{i}^{X}}{\partial p_{i}^{K L E}}$ with $\perp p_{i}^{K L E}$ 
Sectoral Domestic Output (for Armington Aggregate and Export Markets)

$\bar{X}_{i} \geq D_{i} \frac{\partial \pi_{i}^{G}}{\partial p_{i}^{D}}+I M_{i} \frac{\partial \pi_{i}^{I M}}{\partial p_{i}^{D}}$ with $\perp p_{i}^{D}$

\section{Import Aggregate}

$I \bar{M}_{i} \geq G_{i} \frac{\partial \pi_{i}^{G}}{\partial p_{i}^{I M}}$ with $\perp p_{i}^{I M}$

\section{Armington Aggregate}

$\bar{G}_{i} \geq X_{i} \frac{\partial \pi_{i}^{X}}{\partial p_{i}^{G}}+W \frac{\partial \pi^{W}}{\partial p^{G}}+W G O V \frac{\partial \pi^{W G O V}}{\partial p^{G}}$ with $\perp p_{i}^{G}$

\section{Household Non-Energy Consumption}

$\overline{N E} \geq W \frac{\partial \pi^{W}}{\partial p^{N E}}$ with $\perp p^{N E}$

\section{Sector-Specific Material Consumption}

$\overline{I N T}_{i} \geq X_{i} \frac{\partial \pi_{i}^{X}}{\partial p_{i}^{I N T}}$ with $\perp p_{i}^{I N T}$

\section{Welfare of Household}

$\bar{W} \geq \frac{I H H}{p^{W}}$ with $\perp p^{W}$

\section{Welfare of Government}

$\overline{W G O V} \geq \frac{I G O V}{p^{W G O V}}$ with $\perp p^{W G O V}$

\section{Income balance conditions}

Income balance condition requires that every agent's income must equal the value of endowments.

Household Income Household income $I H H$ equals the total value of labor and capital income of private households (wage rate $\omega$ times benchmark labor endowment $\bar{L}$ plus rental rate $v$ (price of capital) times benchmark capital endowment $(\bar{K})$ plus unemployment benefits (UBEN) and other transfers (TRANS) from the government.

$$
I H H=\omega \bar{L}+v \bar{K}+\overline{U B E N}+\overline{T R A N S}=\bar{W}
$$

In addition, the private household is endowed with annual savings $\overline{S A V E}$ and depreciation $\overline{D E P R}$, which drive the extent of annual investment. However, the composition of investments is flexible, hence the household does not decide whether to consume or invest, since investment is given exogenously.

$p_{I N V} \overline{I N V}=\overline{D E P R}+\overline{S A V E}$

\section{Government Income}

$I G O V=T A X+F O L E$

with FOLE being foreign lending.

$$
\begin{aligned}
T A X= & \omega \bar{L} \bar{t}^{L}+v \bar{K} \bar{t}^{K}+\sum_{i} p_{i}^{X} X_{i} \bar{t}_{i}^{X}+\sum_{i} p_{i}^{E X} \overline{E X}_{i} \bar{t}_{i}^{E X} \\
\overline{W G O V}= & I G O V-U B E N-T R A N S \\
I G O V= & \omega \bar{L} \bar{t}^{L}+v \bar{K} \bar{t}^{K}+\sum_{i} p_{i}^{X} X_{i} \bar{t}_{i}^{X}+\sum_{i} p_{i}^{E X} \overline{E X}_{i} \bar{t}_{i}^{E X} \\
& + \text { FOLE }
\end{aligned}
$$

Open Access This article is distributed under the terms of the Creative Commons Attribution 4.0 International License (http:// creativecommons.org/licenses/by/4.0/), which permits unrestricted use, distribution, and reproduction in any medium, provided you give appropriate credit to the original author(s) and the source, provide a link to the Creative Commons license, and indicate if changes were made.

\section{References}

1. Perry, M., \& Ciscar, J. (2014). Multi-sectoral perspective in modelling of climate impacts and adaptation. In I. Galarraga \& E. Sainz de Murieta (Eds.), Routledge Handbook of the Economics of Climate Change Adaptation. London: Routledge.

2. Aaheim, A., Amundsen, H., Dokken, T., \& Wei, T. (2012). Impacts and adaptation to climate change in European economies. Global Environmental Change, 22(4), 959-968.

3. Ciscar, J., Feyen, L., Soria, A., Lavalle, C., Raes, F., Perry, M., ... Ibarreta, D. (2014). Climate Impacts in Europe. Results from the JRC PESETA II Project.

4. Steininger, K. W., König, M., Bednar-Friedl, B., Kranzl, L., Loibl, W., \& Prettenthaler, F. (Eds.). (2015). Economic Evaluation of Climate Change Impacts. Development of a Cross-Sectoral Framework and Results for Austria. Berlin: Springer.

5. Jones, B., Keen, M., \& Strand, J. (2013). Fiscal implications of climate change. International Tax and Public Finance, 20(1), 2970. https://doi.org/10.1007/s10797-012-9214-3.

6. Lis, E. M., \& Nickel, C. (2010). The impact of extreme weather events on budget balances. International Tax and Public Finance, 17(4), 378-399. https://doi.org/10.1007/s10797-010-9144-x.

7. Goulder, L. H. (1995). Environmental taxation and the double dividend: a reader's guide. International Tax and Public Finance, 2(2), 157-183. https://doi.org/10.1007/BF00877495.

8. Jorgenson, D. W., \& Wilcoxen, P. J. (1993). Reducing US carbon emissions: an econometric general equilibrium assessment. Resource and Energy Economics, 15(1), 7-25. https://doi.org/10. 1016/0928-7655(93)90016-N. 
9. Parry, I. W. (1995). Pollution taxes and revenue recycling. Journal of Environmental Economics and Management, 29(3), S64-S77. https://doi.org/10.1006/jeem.1995.1061.

10. Pearce, D. (1991). The role of carbon taxes in adjusting to global warming. The Economic Journal, 101(407), 938. https://doi.org/10. 2307/2233865.

11. Repetto, R. C., Dower, R. C., Jenkins, R., \& Geoghegan, J. (1992). Green fees: how a tax shift can work for the environment and the economy. Washington, DC: World Resources Institute.

12. Bor, Y. J., \& Huang, Y. (2010). Energy taxation and the double dividend effect in Taiwan's energy conservation policy - an empirical study using a computable general equilibrium model. Energy Policy, 38(5), 2086-2100. https://doi.org/10.1016/j.enpol.2009.06.006.

13. Goulder, L. H. (2013). Climate change policy's interactions with the tax system. Supplement Issue: Fifth Atlantic Workshop in Energy and Environmental Economics, 40, Supplement 1, S3-S11. doi: https://doi.org/10.1016/j.eneco.2013.09.017

14. Fischer, C., \& Fox, A. K. (2012). Climate policy and fiscal constraints: do tax interactions outweigh carbon leakage? Energy Economics, 34, S218-S227. https://doi.org/10.1016/j.eneco.2012.09.004.

15. Rausch, S. (2013). Fiscal consolidation and climate policy: an overlapping generations perspective. Energy Economics, 40, S134S148. https://doi.org/10.1016/j.eneco.2013.09.009.

16. Franks, M., Edenhofer, O., \& Lessmann, K. (2015). Why finance ministers favor carbon taxes, even if they do not take climate change into account. Environmental and Resource Economics. doi:https://doi.org/10.1007/s10640-015-9982-1

17. UNISDR. (2015). Making development sustainable: the future of disaster risk management. Geneva: United Nations Office for Disaster Risk Reduction (UNISDR).

18. Hochrainer-Stigler, S., Mechler, R., Pflug, G., \& Williges, K. (2014). Funding public adaptation to climate-related disasters. Estimates for a global fund. Global Environmental Change, 25, 87-96. https://doi.org/10.1016/j.gloenvcha.2014.01.011.

19. Cummins, J. D., \& Mahul, O. (2009). Catastrophe risk financing in developing countries: principles for public intervention. Washington, D.C: World Bank.

20. World Bank. (2010). The Cost to Developing Countries of Adapting to Climate Change: New Methods and Estimates (Consultation draft). World Bank, Washington.

21. Osberghaus, D., \& Reif, C. (2010). Total costs and budgetary effects of adaptation to climate change: an assessment for the European Union. ZEW-Centre for European Economic Research Discussion Paper, (10-046). Retrieved from http://papers.ssrn. com/sol3/papers.cfm?abstract_id=1649452

22. Leppänen, S., Solanko, L., \& Kosonen, R. (2015). The impact of climate change on regional government expenditures: evidence from Russia. Environmental and Resource Economics. https://doi. org/10.1007/s10640-015-9977-y.

23. Delpiazzo, E., Parrado, R., \& Bosello, F. (2015). Analyzing the coordinated impacts of climate policies for financing adaptation and development actions (No. RP0276). CMCC. Retrieved from https://www. gtap.agecon.purdue.edu/resources/download/7978.pdf

24. Bräuer, I., Umpfenbach, K., Blobel, D., Grünig, M., Best, A., Peter, M., ... Kasser, F. (2009). Klimawandel: Welche Belastungen entstehen für die Tragfähigkeit der Öffentlichen Finanzen? Endbericht, Ecologic Institute, Berlin. Retrieved from http://www. ecologic.eu/download/projekte/1850-1899/1865/Endbericht FINAL_Klimawandel.pdf

25. Bachner, G., Bednar-Friedl, B., Nabernegg, S., \& Steininger, K. W. (2015). Macroeconomic evaluation of climate change in Austria: a comparison across impact fields and total effects. In K. W. Steininger, M. König, B. Bednar-Friedl, L. Kranzl, W. Loibl, \& F. Prettenthaler (Eds.), Economic Evaluation of Climate Change Impacts: Development of a Cross-Sectoral Framework and Results for Austria (pp. 415-440). Berlin: Springer.
26. Bachner, G., Bednar-Friedl, B., Nabernegg, S., \& Steininger, K. W. (2015). Economic evaluation framework and macroeconomic modelling. In K. W. Steininger, M. König, B. Bednar-Friedl, L. Kranzl, W. Loibl, \& F. Prettenthaler (Eds.), Economic Evaluation of Climate Change Impacts: Development of a Cross-Sectoral Framework and Results for Austria (pp. 101-120). Berlin: Springer.

27. Armington, P. S. (1969). A theory of demand for products distinguished by place of production (Une theorie de la demande de produits differencies d'apres leur origine) (Una teoria de la demanda de productos distinguiendolos segun el lugar de produccion). Staff Papers-International Monetary Fund, 16(1), 159. https://doi.org/10.2307/3866403.

28. O'Neill, B. C., Kriegler, E., Riahi, K., Ebi, K. L., Hallegatte, S., Carter, T. R., et al. (2014). A new scenario framework for climate change research: the concept of shared socioeconomic pathways. Climatic Change, 122(3), 387-400. https://doi.org/10.1007/s10584-013-0905-2.

29. Hanika, A. (2010). Kleinräumige Bevölkerungsprognose für Österreich 2010-2030 mit Ausblick bis 2050 ("ÖROKPrognosen") Teil 1: Endbericht zur Bevölkerungsprognose. Vienna: ÖROK. Retrieved from http://www.oerok.gv.at/raumregion/daten-und-grundlagen/oerok-prognosen/oerok-prognosen2010.html

30. Hanika, A. (2005). ÖROK-Prognosen 2001-2031; Teil 2 Haushalte und Wohnungsbedarf nach Regionen und Bezirken Österreichs. (No. 166/2). Vienna: ÖROK. Retrieved from http://www.oerok. gv.at/raum-region/daten-und-grundlagen/oerok-prognosen/oerokprognosen-2010.html

31. Schiman, S., \& Orischnig, T. (2012). Coping with potential impacts of ageing on public finances in Austria; the Demography-based Economic Long-Term Model for Austria's Public Finances (DELTA-BUDGET) assumption report (No. 1/2012). Vienna, Austria: Austrian Federal Ministry of Finance.

32. IEA. (2010). World Energy Outlook 2010. Paris, France: International Energy Agency.

33. OECD/FAO. (n.d.). OECD-FAO agricultural outlook 2013-2022. Paris, France: OECD.

34. König, M., Loibl, W., Haas, W., \& Kranzl, L. (2015). Shared-socioeconomic pathways. In K. W. Steininger, M. König, B. BednarFriedl, L. Kranzl, \& F. Prettenthaler (Eds.), Economic Evaluation of Climate Change Impacts: Development of a Cross-Sectoral Framework and Results for Austria. Berlin: Springer.

35. Formayer, H., Nadeem, I., \& Anders, I. (2015). Climate change scenario: from climate model ensemble to local indicators. In K. W. Steininger, M. König, B. Bednar-Friedl, L. Kranzl, W. Loibl, \& F. Prettenthaler (Eds.), Economic Evaluation of Climate Change Impacts. Development of a Cross-sectoral Framework and Results for Austria (pp. 55-74). Cham: Springer International Publishing. https://doi.org/10.1007/978-3-319-12457-5_2

36. Austrian Panel on Climate Change, \& Kromp-Kolb, H. (Eds.). (2014). Österreichischer Sachstandsbericht Klimawandel $2014=$ : Austrian assessment report 2014 (AAR14). Wien: Verlag der Österreichischen Akademie der Wissenschaften.

37. Meissner, C. S., Panitz, H.-J. F., \& Kottmeier, C. (2009). Highresolution sensitivity studies with the regional climate model COSMO-CLM. Meteorologische Zeitschrift, 18(5), 543-557. https://doi.org/10.1127/0941-2948/2009/0400.

38. EC. (2018). Convergence criteria for joining. Convergence criteria for joining_European Commission. Retrieved January 13, 2018, from https://ec.europa.eu/info/business-economy-euro/euro-area/ enlargement-euro-area/convergence-criteria-joining en

39. Hochrainer-Stigler, S., Lugeri, N., \& Radziejewski, M. (2014). Upscaling of impact dependent loss distributions: a hybrid convolution approach for flood risk in Europe. Natural Hazards, 70(2), 14371451. https://doi.org/10.1007/s11069-013-0885-6. 
40. Rojas, R., Feyen, L., \& Watkiss, P. (2013). Climate change and river floods in the European Union: socio-economic consequences and the costs and benefits of adaptation. Global Environmental Change, 23(6), 1737-1751. https://doi.org/10.1016/j.gloenvcha.2013.08.006.

41. Feyen, L., \& Watkiss, P. (2011). The impacts and economic costs of river floods in Europe and the costs and benefits of adaptation. Summary of sector results from the EC RTD ClimateCost Project.

42. Mathiesen, L. (1985). Computational experience in solving equilibrium models by a sequence of linear complementarity problems. Operations Research, 33(6), 1225-1250.

43. Böhringer, C., \& Wiegard, W. (2002). Methoden der angewandten Wirtschaftsforschung: Eine Einführung in die numerische Gleichgewichtsanalyse (No. 03-02). Mannheim: Zentrum für Europäische Wirtschaftsforschung.

44. Mitter, H., Schönhart, M., Meyer, I., Schmid, E., \& Sinabell, F. (2015). Agriculture. In K. W. Steininger, M. König, B. BednarFriedl, L. Kranzl, W. Loibl, \& F. Prettenthaler (Eds.), Economic Evaluation of Climate Change Impacts. Development of a Crosssectoral Framework and Results for Austria (pp. 123-146). Cham: Springer International Publishing. https://doi.org/10.1007/978-3319-12457-5 15

45. Izaurralde, R. C., Williams, J. R., McGill, W. B., Rosenberg, N. J., \& Jakas, M. C. Q. (2006). Simulating soil C dynamics with EPIC: Model description and testing against long-term data. Ecological Modelling, 192(3-4), 362-384. https://doi.org/10.1016/j. ecolmodel.2005.07.010.

46. Schmid, E. (2004). The Positive Agricultural Sector Model Austria-PASMA. Vienna: University of Agriculture and Life Sciences.

47. Schörghuber, S., Seidl, R., Rammer, W., Kindermann, G., \& Lexer, M. J. (2010). KlimAdapt - Ableitung von prioritären Maßnahmen zur Adaption des Energiesystems an den Klimawandel Arbeitspaket 3: Biomasse Bereitstellung (Technical Report). Vienna: University of Agriculture and Life Sciences.

48. Seidl, R., Schelhaas, M.-J., Lindner, M., \& Lexer, M. J. (2009). Modelling bark beetle disturbances in a large scale forest scenario model to assess climate change impacts and evaluate adaptive management strategies. Regional Environmental Change, 9(2), 101119. https://doi.org/10.1007/s10113-008-0068-2.

49. Seidl, R., Schelhaas, M.-J., \& Lexer, M. J. (2011). Unraveling the drivers of intensifying forest disturbance regimes in Europe: drivers of forest disturbance intensification. Global Change Biology, 17(9), 2842-2852. https://doi.org/10.1111/j.1365-2486.2011.02452.x.

50. Lexer, M. J., Jandl, R., Nabernegg, S., \& Bednar-Friedl, B. (2015). Forestry. In K. W. Steininger, M. König, B. Bednar-Friedl, L. Kranzl, W. Loibl, \& F. Prettenthaler (Eds.), Economic Evaluation of Climate Change Impacts. Development of a Cross-sectoral Framework and Results for Austria (pp. 147-167). Cham: Springer International Publishing. doi:https://doi.org/10.1007/9783-319-12457-5 15

51. Kranzl, L., Matzenberger, J., Totschnig, G., Toleikyte, A., Schicker, I., \& Formayer, H. (2014). Power through resilience of energy system (Final report of the project PRESENCE. Project in the frame of the Austrian climate research program). Vienna. Retrieved from http://www.eeg.tuwien.ac.at/eeg.tuwien.ac.at_pages/research/ down 1 oads/PR_356_B 068675 PRESENCE FinalPublishableReport submitted.pdf

52. Kranzl, L., Totschnig, G., Müller, A., Bachner, G., \& Bednar-Friedl, B. (2015). Electricity. In K. W. Steininger, M. König, B. BednarFriedl, L. Kranzl, W. Loibl, \& F. Prettenthaler (Eds.), Economic Evaluation of Climate Change Impacts. Development of a Crosssectoral Framework and Results for Austria (pp. 257-278). Cham: Springer International Publishing. doi:https://doi.org/10.1007/9783-319-12457-5 15

53. Totschnig, G., Kann, A., Truhetz, H., Pfleger, M., \& Schauer, G. (2013). AutRES100-Hochauflösende Modellierung des
Stromsystems bei hohem erneuerbaren Anteil - Richtung 100\% Erneuerbare in Österreich (AS NE 2020 Endbericht No. 3). Vienna, Austria.

54. Totschnig, G., Hirner, R., Mueller, A., Kranzl, L., Hummel, M., Nachtnebel, H. P., ... Formayer, H. (2013). Climate change impact on the electricity sector: the example of Austria and Germany (PRESENCE Working Paper). Vienna, Austria: Energy Economics Group, Vienna University of Technology. Retrieved from www.eeg.tuwien.ac.at/eeg.tuwien.ac.at_pages/research/ downloads/PR 35608 PRESENCE electricity working paper. pdfl

55. Köberl, J., Prettenthaler, F., Nabernegg, S., \& Schinko, T. (2015). Tourism. In K. W. Steininger, M. König, B. Bednar-Friedl, L. Kranzl, W. Loibl, \& F. Prettenthaler (Eds.), Economic Evaluation of Climate Change Impacts: Development of a Cross-Sectoral Framework and Results for Austria (pp. 367-388). Cham: Springer.

56. Feyen, L., \& Watkiss, P. (2011). The impacts and economic costs of river floods in Europe and the costs and benefits of adaptation.

57. Lugeri, N., Kundzewicz, Z. W., Genovese, E., Hochrainer, S., \& Radziejewski, M. (2010). River flood risk and adaptation in Europe-assessment of the present status. Mitigation and Adaptation Strategies for Global Change, 15(7), 621-639. https:// doi.org/10.1007/s11027-009-9211-8.

58. Kundzewicz, Z. W., Lugeri, N., Dankers, R., Hirabayashi, Y., Döll, P., Pińskwar, I., et al. (2010). Assessing river flood risk and adaptation in Europe - review of projections for the future. Mitigation and Adaptation Strategies for Global Change, 15(7), 641-656. https://doi.org/10.1007/s11027-010-9213-6.

59. Neunteufel, R., Perfler, R., Schwarz, D., Bachner, G., \& BednarFriedl, B. (2015). Water supply and sanitation. In K. W. Steininger, M. König, B. Bednar-Friedl, L. Kranzl, W. Loibl, \& F. Prettenthaler (Eds.), Economic Evaluation of Climate Change Impacts. Development of a Cross-sectoral framework and Results for Austria (pp. 215-234).

60. Müller, A. (2015). Energy demand assessment for space conditioning and domestic hot water: a case study for the Austrian building stock. Vienna: Vienna University of Technology.

61. Kranzl, L., Hummel, M., Müller, A., \& Steinbach, J. (2013). Renewable heating: perspectives and the impact of policy instruments. Energy Policy, 59, 44-58. https://doi.org/10.1016/j.enpol. 2013.03.050.

62. Müller, A., Biermayr, P., Kranzl, L., Haas, R., Altenburger, F., Weiss, W., ... Ohnmacht, R. (2010). Heizen 2050: Systeme zur Wärmebereitstellung und Raumklimatisierung im österreichischen Gebäudebestand: Technologische Anforderungen bis zum Jahr 2050. Vienna: Vienna University of Technology.

63. Bednar-Friedl, B., Wolkinger, B., König, M., Bachner, G., Formayer, H., Offenthaler, I., \& Leitner, M. (2015). Transport. In K. W. Steininger, M. König, B. Bednar-Friedl, L. Kranzl, W. Loibl, \& F. Prettenthaler (Eds.), Economic Evaluation of Climate Change Impacts. Development of a Cross-sectoral Framework and Results for Austria (pp. 279-300). Cham: Springer International Publishing. https://doi.org/10.1007/978-3-319-12457-5_15

64. Urban, H., \& Steininger, K. W. (2015). Manufacturing and trade: labour productivity losses. In K. W. Steininger, M. König, B. Bednar-Friedl, L. Kranzl, W. Loibl, \& F. Prettenthaler (Eds.), Economic Evaluation of Climate Change Impacts: Development of a Cross-sectoral Framework and Results for Austria (pp. 301322). Berlin: Springer.

65. Kjellstrom, T., Kovats, R. S., Lloyd, S. J., Holt, T., \& Tol, R. S. J. (2009). The direct impact of climate change on regional labor productivity. Archives of Environmental and Occupational Health, 64(4), 217-227. https://doi.org/10.1080/19338240903352776.

66. Loibl, W., Tötzer, T., Köstl, M., Nabernegg, S., \& Steininger, K. W. (2015). Cities and urban green. In K. W. Steininger, M. König, B. Bednar-Friedl, L. Kranzl, W. Loibl, \& F. Prettenthaler (Eds.), 
Economic Evaluation of Climate Change Impacts. Development of a Cross-Sectoral framework and Results for Austria (pp. 323-348). Berlin: Springer.
67. Gill, S., Handley, J., Ennos, R., \& Pauleit, S. (2007). Adapting cities for climate change: the role of the green infrastructure. Built Environ, 30(1), 97-115. 